Historic, archived document

Do not assume content reflects current scientific knowledge, policies, or practices. 



\section{$\frac{62}{1890}$ POMONA NURSERIES. 1809

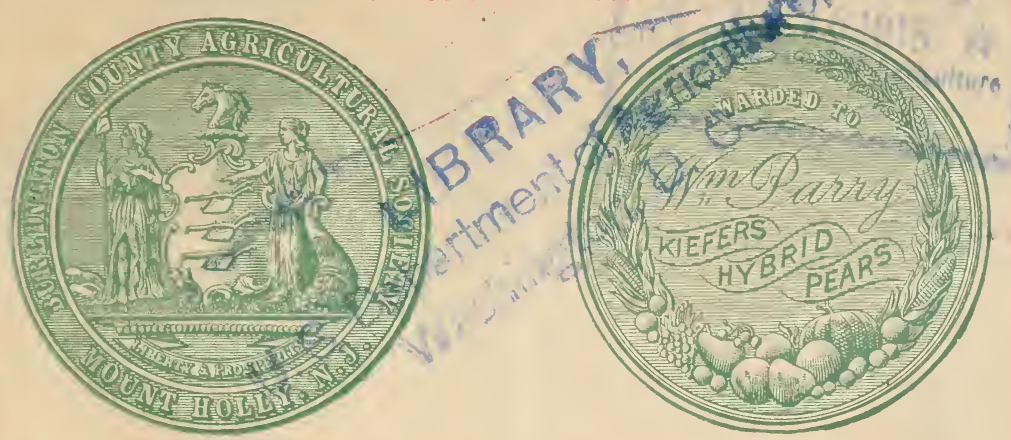 \\ STRAWBERRIES, BLACKBERRIES, \\ RASPBERRIES,}

GRAPES, CURRANTS, GOOSEBERRIES, RHUBARB AND ASPARAGUS.

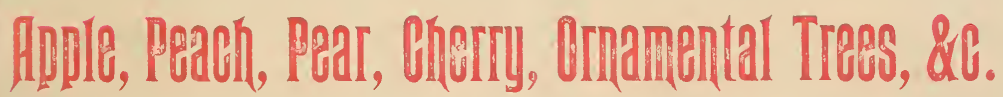

fruits grow ror markbi and plants por sal?.

\section{FFALL, 1885.}

\section{WILLIAM PARRY, PARRY P. O., N. J.}

Riverton Station, Penna. R. R., Amboy Division.

Stages running between Pomona Narseries and Riverton station connect with trains leaving Philadelphia, 7.20 and $10.30 \mathrm{~A}$. M, 2.30 and 4.30 P. M. ; leaving Riverton for Philadelphia 7.61 and $9.56 \mathrm{~A}, \mathrm{M}_{1,}, 2.30$ and $5.08 \mathrm{P}, \mathrm{M}$. 
To those who have not had an opportunity to risit POMONA NURSERIES. the following unsolucited notices from the pres mar wive some !nformation :

\section{From the West Jersey Pres:}

Judge Parry, of Parry P. (O.. N. J , the weil and widely known fruit and berry culturist, has in process of propagation a new variety of Pear. Kieffer's Hybrid, which gives promise of great productiveness and profit. His long experience and conceded skill in this department of agriculture are quite sufficient to give a large sale to any fruit he endorses. No man in this country has done more to bring to notice the triumphs of fruit and leer! culture than he has, and to him more than any other man. perhaps, is the country indebted for the excellence of the fruits with which our markets have been supplied

\section{From the Journal of Commerce.}

\section{THE P(OMONA NURSERHIS:}

In $\iota_{3} 8, \mathrm{Mr}$. William Pary commenced, on a comparatrely smali sciale, the nursery business. From that date to the present he has cultivated the same homestead farm of orer three hundred acres, and which is now known throughout the country by its title of Pomona Nurseries. It is the finest and most extensive in the State of New Jersey (being located about eight miles froi Camden, on the Westfield pike). Of its large acreage about one hundred are devoted to the culture of the smaller fruits. Every new fruit is carefully tested before being sent out to the public. Mr. Parry has supplied many of the largest fruit farms in the country, and seldom loses a customer once made. There is no danger of getting any inferior stock from the Pomona Nurncries: as Mr. Parry's experience of fifty years enables him to judge pretty well the products of his large farm. His main attention is given to fruits. and much is due to him for the increased interest taken in fruit culture in thin State and section. His lists comprise fine assortments of apples, dwarf and standard pears, plums, peaches, quinces, nectarines, apricots, grapes and al the smaller fruits. In these latter, Mr. Parry is not excelled or equalled br any other grower in the country. His Sharpless Seedling Strawberry in known all over the Union, while his Gregg and Queen Raspberries are premmm "in ners wherever they go. The Gregg is a black berry, larger, firmer and better flavored than the greater number of red berries. The Queen is red and is fine and large, selected specimens measuring three inches around. It is a wonderful grower, profuse, and yielding a firm berry that does not settle down and bruist in the boxes. Growers will do well to pay Mr. Parry a visit and examine his nursery. They will find what could not be told in the Journal under a couple of columms, at least. Such a visit would be more than repaid Mr. Parry' address is Parry P. O.. Burlington county, Nen Jerser. 


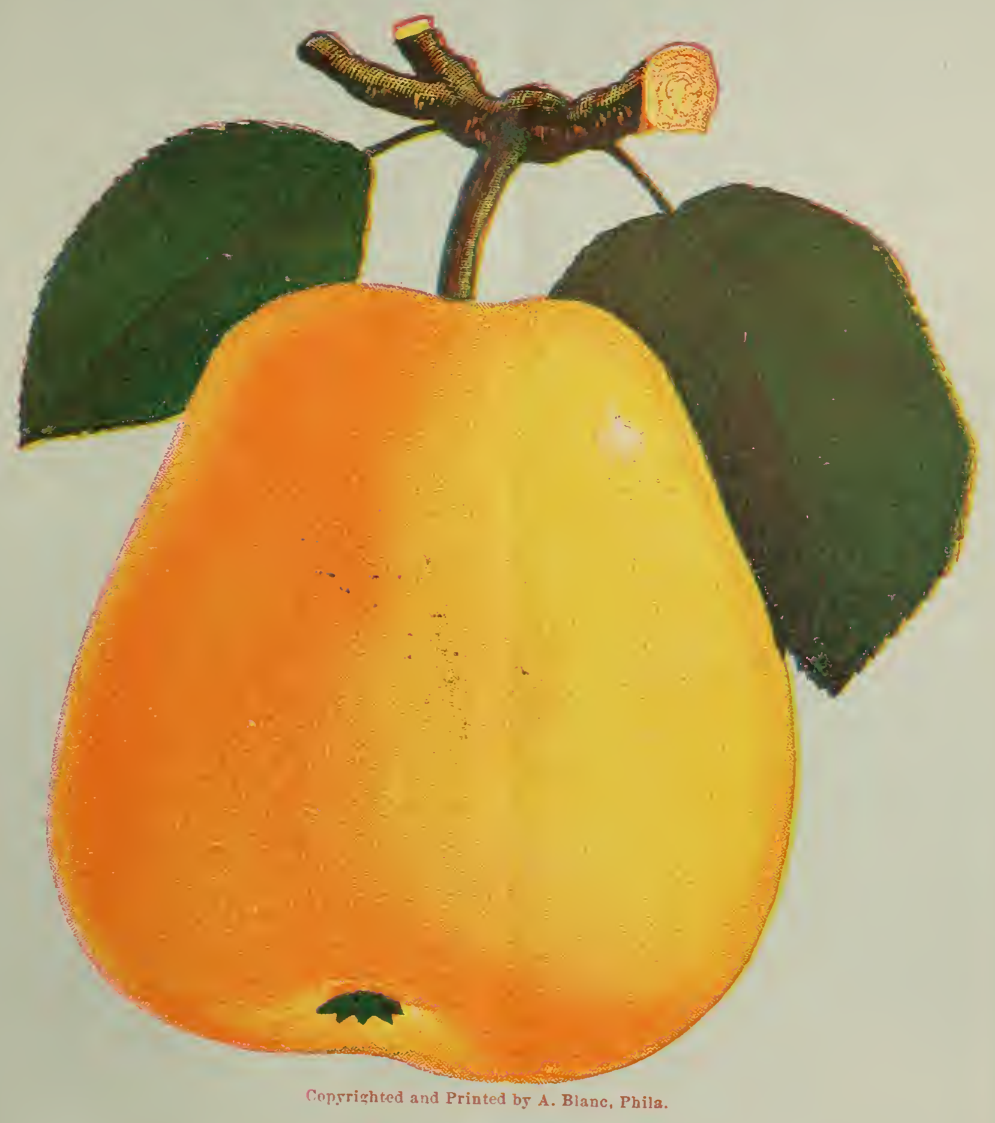

\section{LaWsør.}

Tre Largest and Mast Eeautiful Fear cf Good Quality Ripening in July.

Fiticher and For Sale by

$$
\begin{gathered}
\text { IIIIIIAIN PARRY P O., N J. } \\
\text { PARR, }
\end{gathered}
$$





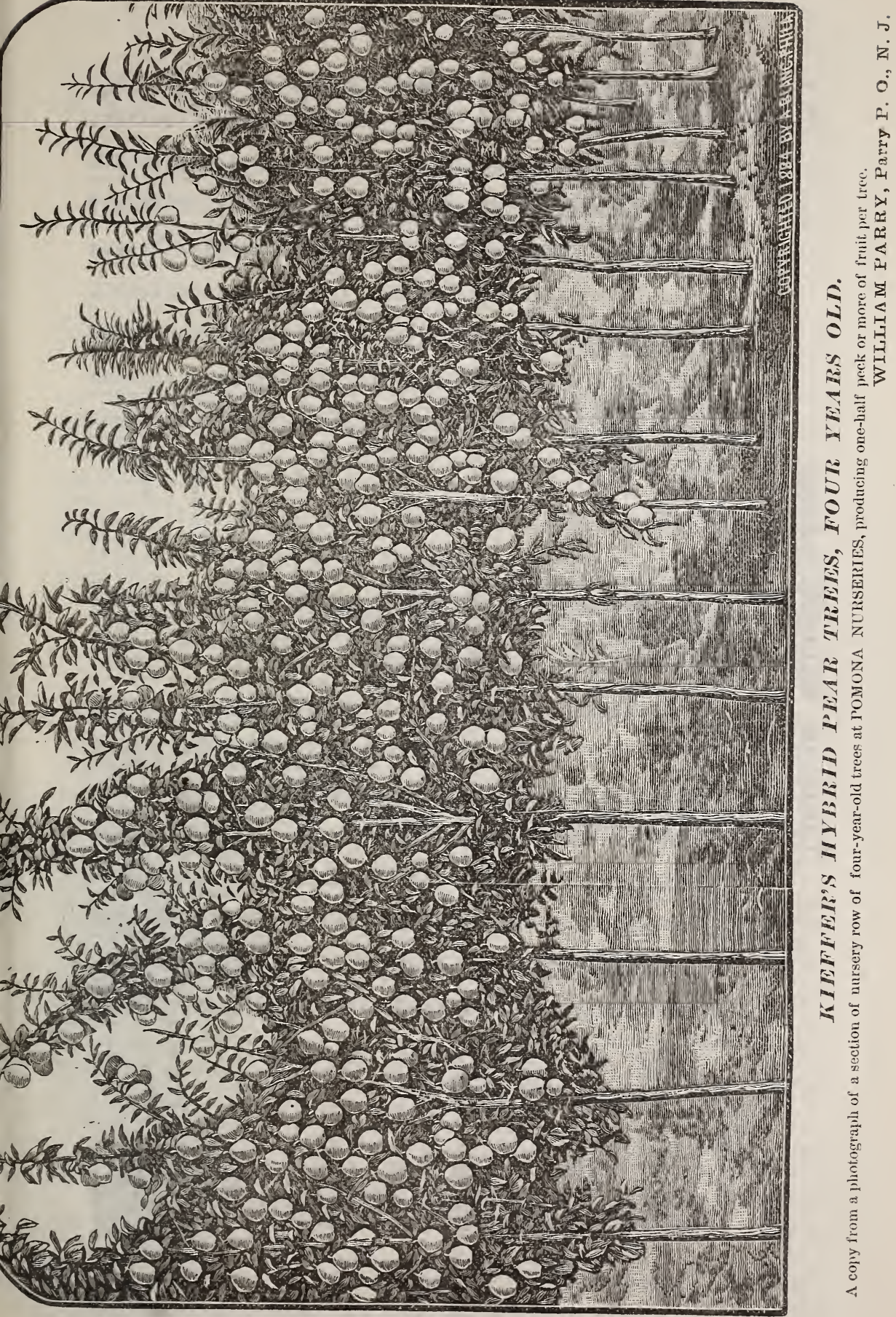




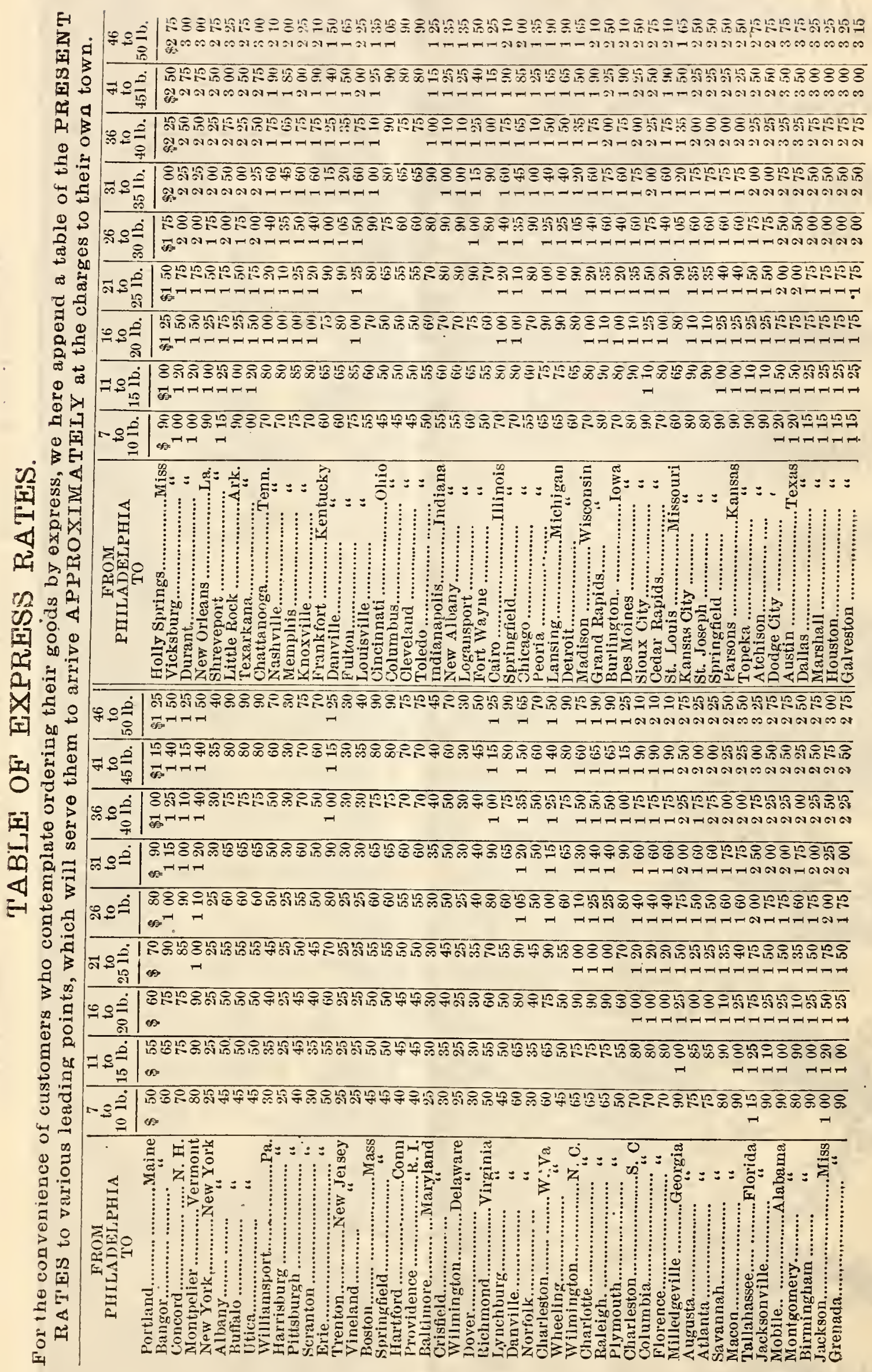




\section{一

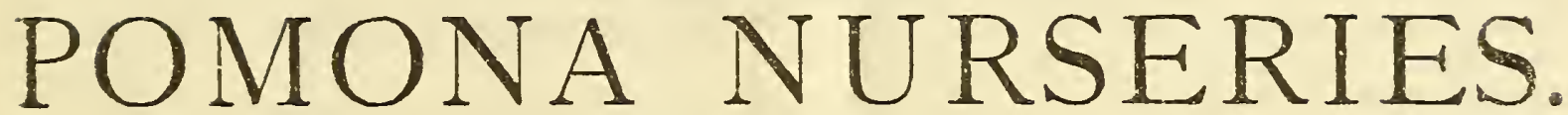

WILLIAM PARRY, PARRY P. O., NEW JERSEY.

EXPRESS, TELEGRAPH AND FREIGHT DEPOT, RIVERTON, N.'].

PENNSYLVANIA RAILROAD--AMBOY DIVISION.

Money Order Office, Moorestown, (not Morristown,) New Jersey.

ESTABLISHED 1838.

\section{FRUITS GROWN FOR MARKET AND PLANTS FOR SALE}

Purchasers cannot fail to appreciate the advantage of dealing directly with a well known fruit grower, who has been engaged fifty years in raising fruits for market, and testing all varieties, over that of buying of irresponsible agents, dealers and others who are but little acquainted with the business, having no fruit of their own growing to sell or exhibit.

The Nurseries are located on the branch of the Westfield and Camden Turnpike, two miles from Riverton, three from Moorestown, eight from Burlington or Philadelphia. A steamboat leaves the latter place for Riverton several times daily, and the cars running between Philadelphia and New York stop at Riverton. Stages running between Pomona Nurseries and Riverton station connect with trains east and west.

Packages for us should be directed to Riverton, N. J., either by express or freight; and Money Orders should be drawn on Moorestown (not Morristown) P. O., Burlington County, N. J., and sent by mail to

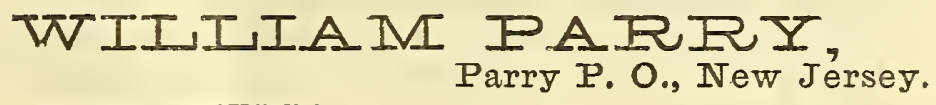

\section{NOTICE TO PURCHASERS.}

Having had fifty years experienee in raising small fruits, with one hundred acres now in cultivation at our nursery, testing new varieties as they come into notice, and discarding those of least value, we now offer for sale a select list that can be relied on for profit. The prominent points are LARGE SIZE, HARDY AND PRODUCTIVE FRUITS. It has been found that of the many new seedlings that are annually brought forward, but comparatively few retain superiority long. Our experimental grounds, on which the different varieties are grown under similar treatment, although expensive, are interesting and useful to those about to form new plantations, and all such are invited to visit our nursery and inspect the different fruits in bearing.

The character for accuracy, promptness and fair dealing, which this establishment has earned and enjoyed for about fifty years, renders it unnecessary for us to publish a list of references or testimonials of assurance that we give prompt and careful attention to all orders with which we are favored, or of the volumes of letters in evidence of our perfect packing, good condition in which the plants are received, satisfactory count, etc.

Fruit growers cannot fail to realize that success depends upon getting genuine, pure, wellgrowen plants, carefully and securely packed. As we have devoted one-half century to the business, and having in our employ, at the heads of our several departments, men who have been with us a quarter of a century and more, and are conversant and familiar with every peculiarity or characteristic of the different varieties of trees and plants, which, under our system of cultivation, guarded care, \&c., renders it next to impossible for our stock to become mixed or impure, or to suffer in transportation; and as "practice makes perfect," we are also enabled to furnish trees and plants pure and unmixed, at the lowest possible prices.

Our packing season for spring begins March Ist, and our first shipments are to the most extreme points South and to the Pacific coast. In the fall we commence in September, and continue through October and November.

When plants are received, take them from the packages, loosen the bunches and dip the roots in a puddle of clay before setting. Don't leave them in the package and pour water on them, as they will surely heat and spoil.

In presenting this, our semi-annual catalogue, we are pleased to announce that our stock of trees and plants is of unusually good quality, more extensive than in former years, and that the umost care and best attention will be given all orders.

Being in direct communication with Philadelphia and New York, our shipping facilities are unsurpassed. 
WEIGHT OF TREES AND PLANTS PACKED.

Fruit Trees................... 5 to 7 feet weigh about $50 \mathrm{lbs}$ to 100 trees.

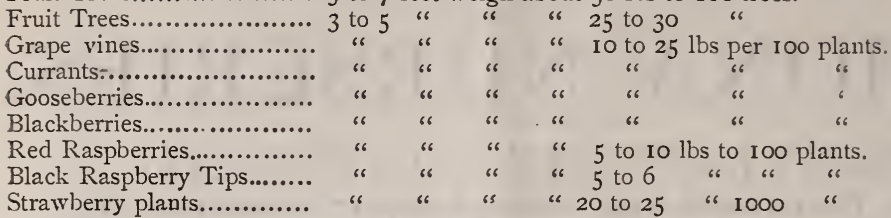

In transporting long distances, where express charges are heavy, roots and tops can be pruned, thereby reducing weights and express charges proportionately.

\section{CONDITIONS OF SALE.}

Should any stock we quote be offered by responsible parties at less rates, for the same grade, we will furnish at the same.

We offer no chromos or prize packages as an inducement to buy our plants but give our patrons more than their value in quality of stock, careful packing, \&c.

The prices of this pamphlet abrogate previous quotations. The prices affixed are for quantities specified, but half-dozen, fifty and five hundred will be supplied at dozen, hundred and thousand rates respectively.

If your order amounts to $\$ 10$ or more, accompanied with the cash, we will furnish an assortment of stock 100 of any kind, at I,000 rates, I dozen or more at 100 rates, one or nore at dozen rates.

Terms cash, unless by special agreement. We will, however, send by express, C. O. D., if 25 per cent. of the amount accompanies the order, although this is an expensive way of remitting. Packing done in the most careful manner.

Packages will be delivered at Riverton Station, free of cost, after which they are at the risk of the purchaser, and in case of loss or delay the purchaser must look to the forwarding companies alone.

When varieties are ordered which we have not, others will be substituted, unless we are requested not to substitute by the person ordering.

No claims will be allowed unless made within ten days after receipt of goods.

Persons who send cash with the order may deduct ten per cent. from the list price, excejt on mail packages.

No discount unless the cash reaches us before shipment.

Money can be sent safely by Post-Office order on Moorestown (not Morristown) P. O., Burlington County, N. J., Bank Check, Draft or Registered Letter, directed to

$$
\text { WILLIAM PARRY, }
$$

Parry P. O., Burlington Co., New Jersey.

\begin{tabular}{|c|c|c|c|c|c|c|c|c|}
\hline A & $\mathrm{D}$ & $\mathrm{A}$ & $\mathrm{D}$ & $\Lambda$ & $\mathrm{D}$ & A & $\mathrm{D}$ & $A$ \\
\hline $\mathrm{D}$ & $\mathrm{S}$ & $\mathrm{D}$ & $\mathrm{S}$ & $\mathrm{D}$ & $s$ & (1) & $\mathrm{s}$ & I \\
\hline A & $\mathrm{D}$ & $\mathrm{A}$ & $\mathrm{D}$ & A & $\mathrm{D}$ & A & D & 2 \\
\hline D & $\mathrm{S}$ & $\mathrm{D}$ & $\mathrm{S}$ & $\mathrm{D}$ & $S$ & D & $=$ & \\
\hline A & $\mathrm{D}$ & $\mathrm{A}$ & $\mathrm{D}$ & A & $\mathrm{D}$ & A & I) & \\
\hline $\mathrm{D}$ & $\mathrm{S}$ & $\mathrm{D}$ & $\mathrm{S}$ & $\mathrm{D}$ & $S$ & $\mathrm{D}$ & 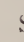 & \\
\hline$A$ & $\mathrm{D}$ & $\mathrm{A}$ & $\mathrm{D}$ & $\mathrm{A}$ & $\mathrm{D}$ & A & D & \\
\hline
\end{tabular}

PLAN OF ORCHARDS.

A. Apple--S. Standard-D. Dwarf Pear, Plum or Peach.

One Acre will contain, at 30 feet apart, 48 Apple Trees, 35 Standard Peaks, 82 Divarf Pear, Peach, \&c.

The advantages of planting fruit trees on the above plan will readily be seen. By setting the Apple trees 30 feet apart, and filling in with smaller growing trees, the Standard Pear occupying the space between the four Apple trees, and being an upright pyramid grower, they do not interfere with each other.

In I863 I planted an Apple Orchard, setting the trees forty feet apart each way; then set a row of Richmond Cherry trees each way between them, requiring three times as many Cherry as Apple trees; then a row of Dorchester Blackberries in the rows and between them, being ten feet apart; then a row of Strawberries between them, leaving five feet of space for cultivation. Next year, 1864 , the Strawberries produced the only crop gathered; they yielded \$200 per acre. 
In I 865 , the Strawberries yielded about half as much, and after picking the fruit the vines were plowed under, and turnips planted in July, which produced a good fall crop. The same year the Blackberries commenced to bear a little and sent up a vigorous growth of canes, which gave a full crop of fruit in $\mathbf{1} 865$, and continued to do so for five years, yielding over $\$ 200$ per acre annually.

The next year they did poorly, and have been removed, to give more room to the trees, which now sufficiently occupy the ground.

The Cherry trees commenced bearing the third year, and have borne full crops every year since, the quantity increasing each year with the size of the trees. For several years the fruit has been worth from $\$ 200$ to $\$ 300$ per acre, and sometimes more. One year we contracted with the , proprietor of a canning factory near by for the whole crop at ten cents per pound. There were eighty trees to the acre, and many of them yielded seventy-five pounds each.

The Apple trees have made a fine growth, and bear large crops of fruit. The Cherry trees in the Apple rows begin to crowd them and will soon be removed, while those standing in the centre of four Apple trees will have plenty of room for many years, and can remain, leaving as many rows of Cherry trees forty feet apart as of Apples on the same ground. By pursuing the above plan, there may be taken from $\$ 200$ to $\$ 300$ worth of fruit per acre annually, before the Apple trees acquire size enough to bear much fruit, and thus avoid the usual objection urged against the planting of Apple orchards, viz : that it requires so long a time before any profit can be derived from the land thus occupied. The same principle will apply to any distance between 30 and 40 feet, and each planter can decide for himself according to the ground to be devoted to fruit. As the heaviest draught upon the soil is when the fruit is ripening, if all matured at once, they might exhaust it of moisture and nourishment, but as they ripen gradually, following in succession, the intervening showers supply each crop as well as if there was no other. By this plan we get 165 trees to the acre, and it is much easier and cheaper to fertilize and cultivate 165 trees to one acre, than to have them spread over 5 or 6 acres, to say nothing of the land saved for other crops. Every farmer should have at least one acre of orchard on the above plan, which should yield $\$ 5$ per tree. But at half that sum they will give more than $\$$ too per acre, with less labor than other crops that yield but small returns.

A pamphlet, illustrated, giving fifty years' experience among small fruits, telling What and How to Plant, also a pamphlet giving fifty years' experience in Pear growing, telling how to avoid Blight and insure good crops.

Either sent by mail for 15 cents. Both, 25 cents.

\section{Fruiri Departimeñ.}

\section{APPLES.}

EACH. DOZ. $100 . \quad 1000$.

First Selection,

SUMMER.

Red Astrachan,

Early Bough,

Eearly Harvest,

Early Hagloe,

William's Favorite,

Parrry's White,

Lippincott E. (Red,)

Siberian Crab,

Tetofsky,

Duchesss of Oldenburg,

20 \$2 OO \$I5 OO \$I 2500

LEADING VARIETIES.

FALL.

Bachelor's Blush,

Fall Pippin,

Gravenstien,

Maiden's Blush,

Orange Pippir,

Porter,

Pine Apple,

Grimes' Golden,

Smokehouse,

Plumb Cider,
WINTER.

Baldwin,

Smith's Cider,

Cooper's Redling,

Fallowater,

Roman Stem,

Ridge Fippin,

Roxbury Russett,

Ben Davis,

Langford,

McIntosh,

YELLOW TRANSPARENT; a new Russian Apple.- "The earliest ripening apple grown." "Full medium size; rich, transparent, lemon yellow color. Flesh melting, juicy, pleasant sub-acid. Ripening ten days earlier than Early Harvest, and is the earliest ripening apple as yet introduced." Valuable for market.

Price, 2 years old, 35 cents each; $\$ 3.50$ per dozen; $\$ 25.00$ per Ioo.

Red Bietigheimer.-A German variety; size, large; color, light yellow, nearly covered with red, making it a most attractive market variety; flesh white, firm, sub-acid, with a brisk pleasant flavor; tree a free grower and abundant bearer. Early fall.

Price, 35 cents each; \$3.50 per dozen.

Charlottentha!er; a new Russian variety, very similar to Yellow Transparent.

Price, I year old, 50 cents each; $\$ 5.00$ per dozen.

Red Cider.-Supposed to be a sport or bud variation from Smith Cider, which it resembles in size, growth of tree, immense bearing habit, quality of fruit and everything except in its beautiful red color-hence its name. It being as highly colored as wine sap, rendering it very valuable for market. Price, I year old, 50 cents each; $\$ 5.00$ per dozen. 
First-Class,

Light,

SUMIMER.

Bloodgood,

Bartlett,

Clapp's Favorite,

First-Class,

Clapp's Favorite,
Belle Lucrative,
Buffum,
Howell,

\section{PEARS-Standard.}

SELECT LIST.

\section{FAIL.}

Buffun,

Howell,

Seckle,

Sheldon.

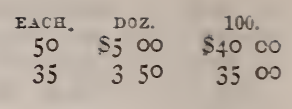

WIITER.

Buerre d'Anjou,

Ticar,

Lawrence.

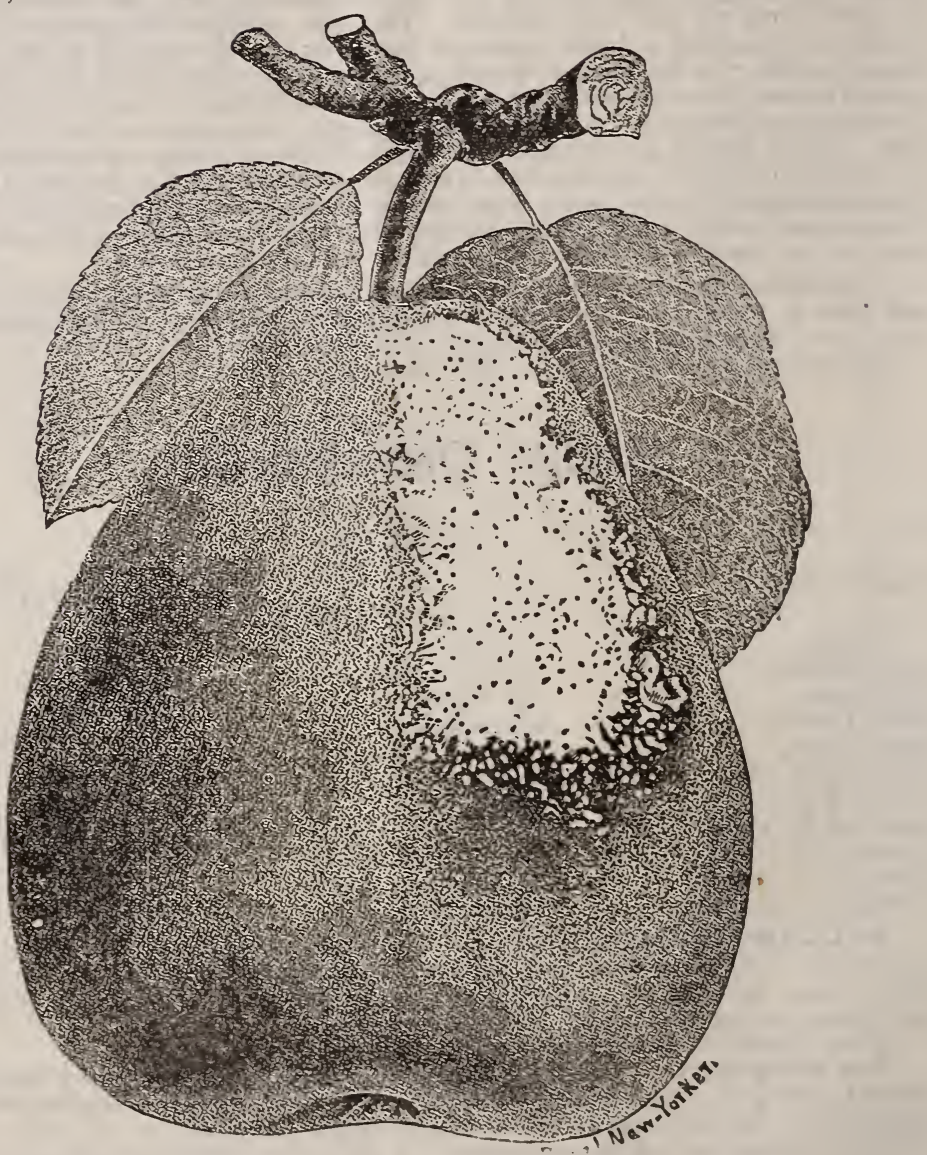

LAWSON PEAR-Introduced and for sale by William Parry.

A vigorous, upright grower with clean, healthy foliage. In an existence of one hundred years it has never been affected with blight or other disease. Very productive and bears young; fruit large, some specimens nine inches around; firm and good shipper; most beautiful red color on yellow ground: flesh crisp, juicy and pleasant, though not best in quality; ripening in Central New York middle of July to first of August. The fruit sold this last summer at $\$ 2.50$ to $\$ 4.00$ per bushel. 
The original tree, estimated to be one hundred or more years old, and shows the impress of ajes, still stands healthy and rigorous in a cleft of a rock in a clump of bushes with no chance of cultivation.

Feeling that the fruit loving public would duly appreciate the opportunity to acquire this beautiful and raluable early pear, and that the good name of LAwsos, on whose farm it originated, should be fondly cherished by posterity, we have, for a valuable consideration, secured the exclusive right and control under contract signed by ALL the heirs, to propagate, sell and introduce this pear to the public, under the true name of LAwsox PEAR.

We procured buds in $\mathrm{IS}_{3}$ from the original tree, which have made a strong healthy growth at PoMoNa Nurseries.

Having introduced the KIEFFER, an October pear, with such gratifying results to the planters, some of whom have set from five to ten thousand trees. we have every confidence that in introducing the LAwsos, a July pear, from its many valuable features as a market fruit, will meet with the same success.

IT IS THE LARGEST AND MOST BEAUTIFUL PEAR OF GOOD QUALITY RIPENING IN JULY in New York State, and when grown in the Middle and Southern States, where it will ripen secera! weeks earlier, and shipped to northern markets, the value as a profitable fruit is apparent.

We were pleased to offer to our patrons in fall of ' $8+$ the first trees of the LAW'sox PEAR that ever were offered for sale.

Our claims for the LAwsox are, that in the past century, or three generations:

It has nerer been known to blight.

It is a vigorous, upright grower.

It is an early bearer.

It is very productive.

It is a good shipping Pear.

It is the earliest large Pear.

It is the largest early Pear.

It is the most beautiful Pear.

It is the most saleable Pear.

All of which combined render it the most profitable early Pear knorrn.

Wilmer Atkinson, in Farm Journal, says: "This Pear promises to make a sensation. The prominent features are that it is the largest early Pear and so fine in appearance that it must meet with ready sale on the fruit stands of the cities

This variety has recently been called Comet by a propagator and sold as a new pear which it is not. Comet is only a new name given to this old variety that has been growing on the Lawson Estate more than one hundred years and is still grown there by the acre.

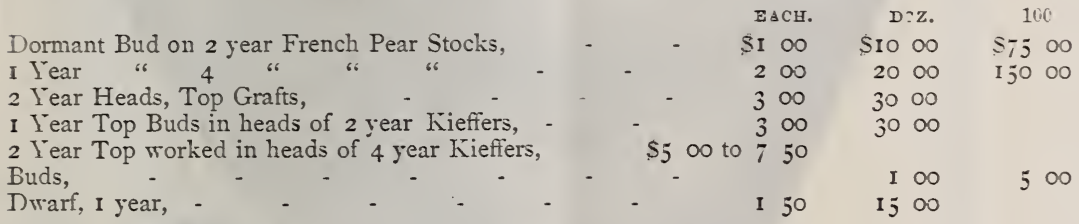

\section{KIEFFER'S HYBRID PEAR.}

This new variety is unquestionably a great acquisition to the list of choice fruits. It is the best of two hundred seedlings, raised from the Chinese Sand Pear, crossed with a cultivated variety supposed to be the Bartlett, which was growing near by the original Sand Pear tree, from which the seed was obtained in or about the year I 868 . This seedling tree commenced fruiting in I873, when about five years of age, and has yielded well every year since-sereral bushels have been gathered of a season. The Chinese Sand Pear, as is well known, is absolutely blight proof, remaining green and rigorous in situations where other varieties blight and die.

\section{ORIENTAL PEARS.}

This race of Pears is remarkable for its vigor of growth, luxuriant foliage, extreme hardiness, and freedom from disease-so that they have been valued as ornamental Lawn Trees, and althougl their fruit is not of the best quality, it has a peculiar quince-like flavor, which, combined with its firmness, makes it superior to any other variety for canning, excelling even the justly famous Bartlett for that purpose.

Of these Oriental Pears, the old Chinese Sand Pear has been most extensively grown and considered the hardiest, and as far as we are aware, has nerer been attacked by blight or any disease, so that it is generally conceded to be blight proof.

Edwin Satterthwaite, the extensire pear grower of Eastern Pennsylvania, states:

"The blight would take entire rows of certain varieties, ruining every tree, until it came to a Sand Pear tree. which it would pass untouched, taking the next. Of several hundred rarieties of pears in my orchard, the Sand Pear was the only variety that had not been aftected with blight, until the introduction of the Keiffer, which thus far has fully held its own with the Sand Pear." 


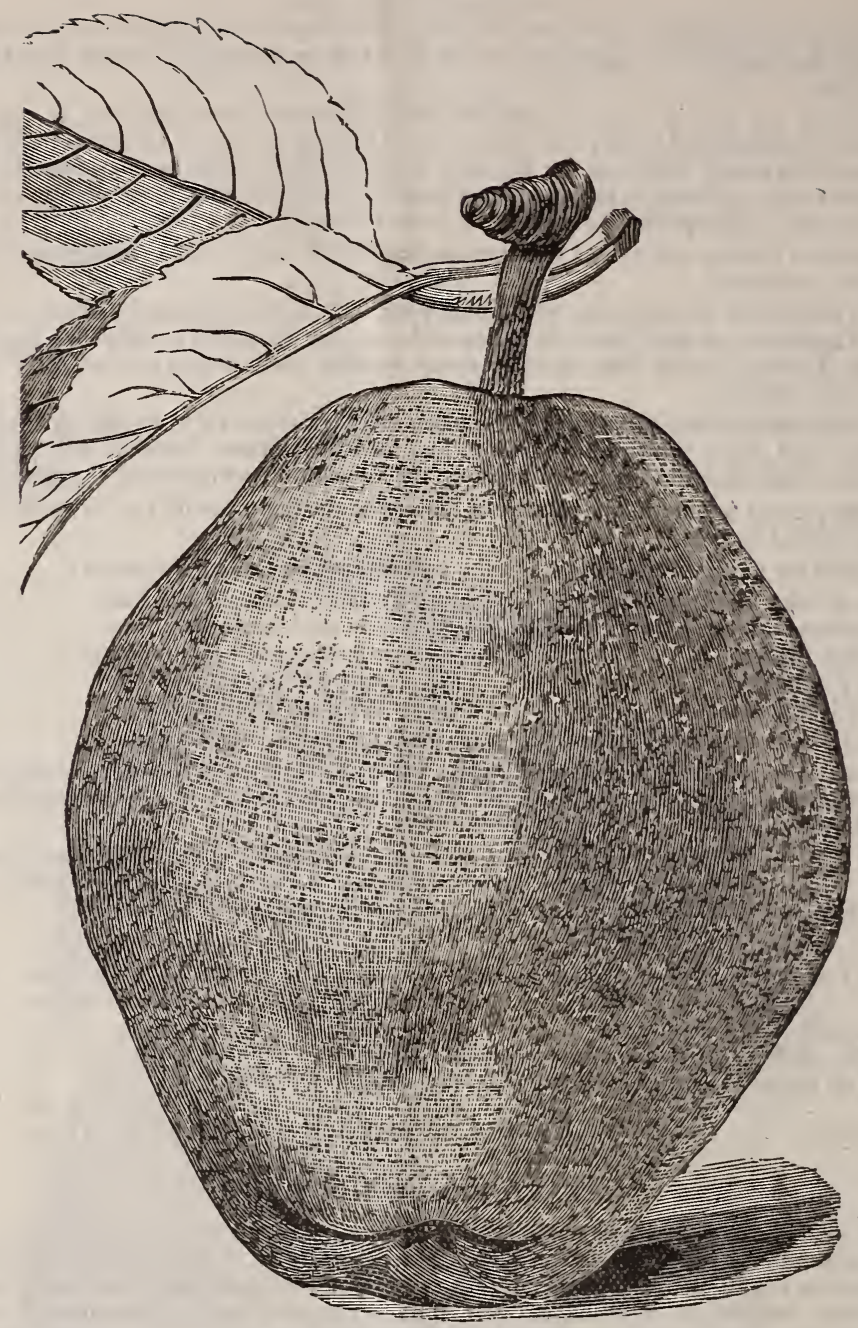

KIEFFER HYBRID PEAR.

J. B. Garber, of Columbia, Penn., says: "He has grown Chinese Sand Pears over forty years, yet not a twig or leaf has been in the least affected by blight or other disease, while other sorts were killed."

Hence we would naturally infer that seedlings of these Ironclads could justly claim stronger constitutions than those of feebler and more delicate parentage.

The Hybrids that we offer, being crossed with our cultivated pears, inherit the hardiness, beautyand vigor of the Orientals, combined with the delicate and delicious flavor of our cultivated varieties, rendering the trees not only valuable as ornaments, but the fruit is also luscious for table use, and unsurpassed for canning and preserving.

The Kieffer Hybrid, like its parent, resists the blight and all other diseases, and has the same healthy, luxuriant foliage, making a strong growth under circumstances where ordinary varieties fail to grow. Yet should it be no better able to resist blight than Bartlett, we consider it much more valuable as a market fruit, being a stronger grower, younger bearer, commencing to produce fruit when three or four years of age, and enormously productive within a few years. Fruit very firm, possessing unequaled shipping qualities. The fruit is large, measuring ten to eleven inches around and weighing as many ounces, and 


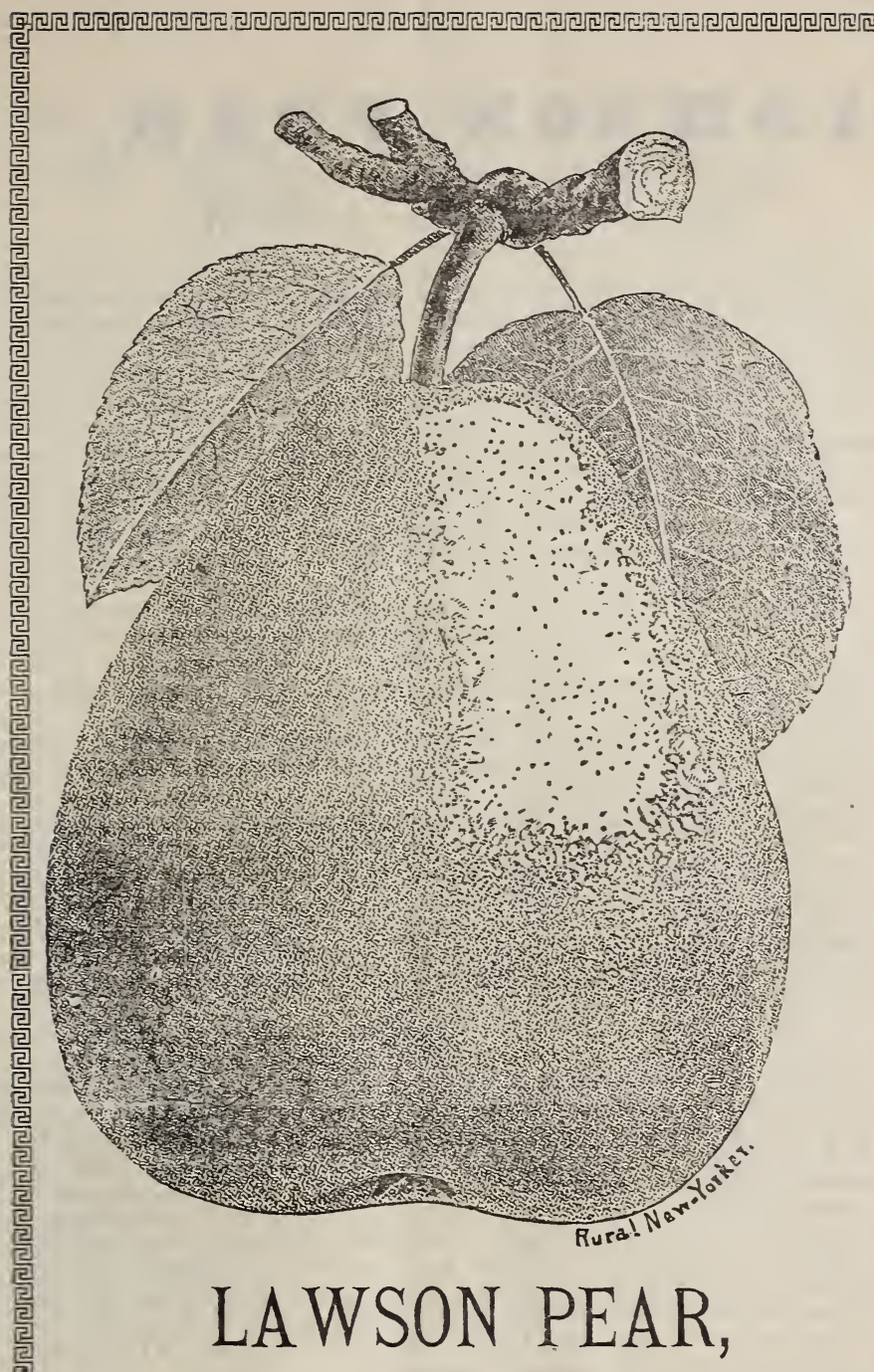

\section{Introduced and for Sale by William Farry,} POMONA NURSERIES, PARRY, N. J. 


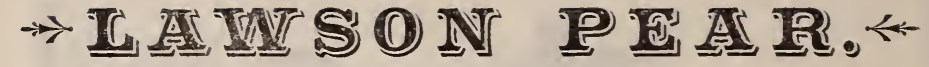

\section{Shall the Name be LAWSON?}

It appears there has been an effort made, which is still continued by a late purchaser, to discard the original name of Lawson which has been associated with this Pear erer since the Elder Lawson purchased in (1832) the estate on which the original tree was then, and is now growing. He first introduced this beautiful Pear to public notice by sending the fruit to New York market, where it attracted much attention and was called Lawson's Pear, it was not necessary for him to go around and tell the people he wanted them to call it by his name, as every body who spoke of it did that, they could do nothing else to identify it with the owner, as he owned the entire stock of this variety then in existence; and all that have since been propagated have descended from the same original tree. He propagated and liad planted several orcbards, around and near the dwellings of his children, which are now taller than the houses in which they live. The writer of this was informed by the present owners. while on the premises looking at the stately old trees, that they werepropagated from the original tree and planted there by their father(John Lawson the elder).

Te solicited some grafts, which were freely giren, and when weoffered to pay for them we were answered "No, they nerer sold any, but had given them to several parties."

Our grafts made a fine growth and when we desired to offer them for sale, we did not feel at liberty to do so without first consulting with the Lawsons and getting their permission for which we were willing to. pay, and went back for the express purpose of negotiating for the privilege and right to put them on the market in a commercial way; and: then made the contract in writing, by which we were given the exclusive privilege of propagating and selling them to others under the name. of Lawson Pear.

A. J. Caywood \& Son in their published letter dated Feb. 23d,1555, in. speaking of this Pear say "a member of the Lawson family gave us grafts, after fruiting it and finding it valuable, we named it Comet." "After. sending Mr. Parry specimens of the fruit he became very much interested, and visited our place, and made offers for purchasing our stock." TVe well remember the pleasant and instructive visit we had there at the special invitation we received to see the "Minnewaski Blackberry and other new fruits," but that was after we had purchased the entire control of the same variety of Pears then in possession of the Lawson family and we had no occasion to purchase more, and have no recollection of making any offer at that time, and if we ever did at any time it must have been on account of his ability and persuasive powers in making us believe, as we did at one time believe, that the Comet was a new pear and the Caywoods had the entire control of it.

But after we found out that there were other orchards older and more. extensive than theirs, belonging to the Lawsons from whom Cay wood first obtained grafts, we went to headquarters and purchased our stock with the exclusive privilege to propagate and sell to others, which had never before been granted to any other person.

In the May number of Gardener's Monthly,page 14t,appeared the following notice: The Comet PE.AR.-Mr. Cay wood complains that a pear which grew on a neighboring farm, and which with that owner's knowledge. and tacit consent he named Comet, has been distributed by another frm as the Lawser." 


\section{HXSTORX OF \\ The Original Lawson Pear Tree.}

This tree, supposed to be one hundred years old, and bears the impress of ages, is still healthy, growing in the cleft of a rock in the county of Ulster, State of New York, on the west bank of the Hudson River, two hundred and fifty feet above its level.

It is located on a part of the farm, which formerly belonged to John Lawson the elder, who first brought it into public notice by grafting and planting orchards of the young trees and sending the fruit to New York markets, where, on account of its earliness and great beauty, it attracted much attention, and was generally called Lawson's Early, Lawson's Beauty, and other prefixes to the orner's name, and sold readily at high prices, which increased as the Pear became better known.

It is the original stock from which all Pear trees of this variety have been grown.

It takes its name from John Lawson the elder, who during his lifetime, owned and occupied the plantation on which it grew and is yet standing.

At the decease of said Joln Lawson the elder, the farm with the original tree and those grown from it descended to his children, then to his grandehildren, who still own and occupy the premises, never having disposed of any trees, buds or scions with the privilege of propagation, for sale or distribution, as its early ripening, handsome color and fine appearance, rendered it a very profitable Pear for market, and solủ last summer from $\$ 2.50$ to $\$ 1.00$ per one-half bushel; yet the Lawsons generously gave to some neighbors and others, grafts to grow for their own use, but not for sule. So that the distribution of this valuable Early Pear was substantially restricted and kept within control of the Lawson family until recently, when for a raluable consideration the exclusive privilege to propagate and sell them to the public, under the name of LATSON PEAR, was conveyed to William Parry by contract in writing signed by all the heirs.

And now the trees are offered for sale by nurserymen and will be widely distributed, and the Public can enjoy one of the most Beautiful and salable Early Market Pears yet introduced. Ripening with the little Doyenne D'ete, but equaling in size and earlier than Beaurre Giffard or Chambers Pears. It is to be regretted that some propagators have called this old rariety by a new name and endeavor to disseminate it as a Tew Fruit, which may lead to confusion. Better apply to headquarters for the genuine stock, the name of which has never been changed, as we purchased the exclusive right to propagate and sell them under the true name of LAWSON PEAR; being the first sale and only one with exclusive privilege ever made of this valuable old variety.

The tree is a vigorous, upright grower, with clean, healthy foliage much resembling the Early Harvest and Jefferson in appearance and habit of growth. In an existence of ONE HUNDRED YEARS, it has never been affected with blight or other disease, is still healthy, and grafts cut from the original tree in $18 \$ 3$ have made rapid growth at POMONA NURSERIES, in BURLINGTON COUNTY, NEW JERSEY.

The daughter of John Lawson the elder, a lady well advanced in years, informs the writer of this, that she well remembers the original tree growing on her father's plantation more than fifty years ago, and it was an old tree then.

The roung trees are rery productive and soon commence bearing. Fruit large, for an early pear, many specimens measure nine inches 


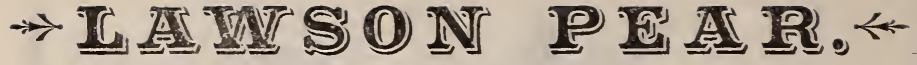

\section{Shall the Name be LAWSON?}

It appears there has been an effort made, which is still continued by a late purchaser, to discard the original name of Lawson which has been associated with this Pear ever since the Elder Lawson purchased in (1S32) the estate on which the original tree was then, and is now growing. He first introduced this beautiful Pear to public notice by sending the fruit to New Fork market, where it attracted much attention and was called Lawson's Pear, it was not necessary for him to go around and tell the people he wanted them to call it by his name, as every body who spoke of it did that, they could do nothing else to identify it with the owner, as he owned the entire stock of this variety then in existence; and all that have since been propagated have descended from the same original tree. He propagated and liad planted several orcbards, around and near the dwellings of his children, which are now taller than the houses in which they live. The writer of this was informed by the present owners. while on the premises looking at the stately old trees, that they werepropagated from the original tree and planted there by their father (John Lawson the elder).

We solicited some grafts, which were freely given, and when weoffered to pay for them we were answered "No, they never sold any, but had given them to several parties."

Our grafts made a fine growth and when we desired to offer them for sale, we did not feel at liberty to do so without first consulting with the Lawsons and getting their permission for which we were willing to pay, and went back for the express purpose of negotiating for the privilege and right to put them on the market in a commercial way; and: then made the contract in writing, by which we were given the exclusive privilege of propagating and selling them to others under the name. of Lawson Pear.

A. J. Caywood \& Son in their published letter dated Feb. 23d,1855, in speaking of this Pear say "a member of the Lawson family gave us grafts, after fruiting it and finding it valuable, we named it Comet." "After sending Mr. Parry specimens of the fruit he became very much interested, and visited our place, and made offers for purchasing our stock.". We well remember the pleasant and instructive visit we had there at the special invitation we received to see the "Ninnewaski Blackberry and other new fruits," but that was after we had purchased the entire control of the same variety of Pears then in possession of the Lawson family and we had no occasion to purchase more, and have no recollection of making any offer at that time, and if we ever did at any time it must have been on account of his ability and persuasive powers in making us believe, as we did at one time believe, that the Comet was a new pear and the Caywoods had the entire control of it.

But after we found out that there were otker orchards older and more. extensive than theirs, belonging to the Lawsons from whom Caywood first obtained grafts, we went to headquarters and purchased our stock with the exclusive privilege to propagate and sell to others, which frad never before been granted to any other person.

In the May number of Gardener's Monthly,page 144,appeared the following notice: The Comet PE.Ar.-Mr. Cay wood complains that a pear which grew on a neighboring farm, and which with that owner's knowledge. and tacit consent he named Conet, has been distributed by another frm. as the Lawson." 
In reply to which the following answer appeared in the June number of Gardener's Monthly, page 176:

\title{
THE COMET PEAR.
}

\author{
BY WM. PARRY.
}

This pear, referred to in the May number of GARDExens' MoNTHLY, was introduced as a new pear, which it is not, but is a very old rariety, beliered to be more than 100 years old. The original tree is still standing on the estate formerly belonging to Joln Lawson the elder, descended to his children and grandchildren, who now own and occupy the premises, having several orchards in bearing, and have marketed 150 crates of pears a season, and to whose generosity the person who applied the name of Comet to this pear is indebted for grafts.

Then we purchased the exclusive privilege of propagating and selling them to others, being the first sale ever made of this variety, a clause was inserted in the contract that it should be "under the true name of Law" "as the Larson," we reply that we are under obligations to do so. Those were the terms of our puichase. We have no right to do otherwise. It was agreed in the contract in writing, that it should be propagated and distributed as the Lawson pear. The children and grandchildren of said John Lawson the elder were not willing that the name of their rerered father and grandfather, who had purchased the premises (their old homestead) on which the original tree was then in full bearing, more than fifty rears ago, should now be discarded by a propagator and a new name giren, and sold as a new variety. The enclose a copy of our contract, and will send a similar one, with the history of the original tree, to all persons who apply for it.

Parry P. O. New Jersey.

[The object of our note was chiefly to note that there was two names given to the same pear by different firms; and the public had a right to know this, in order to be kept from buying the same tree twice orer. As to the right of the question, there can be no question that the owners of the original tree have the right to name it. They say its name is Lawson, and Lawson it must be.-Ed. G. M.]

\section{THE LAWSON PEAR.}

In the JuJy number of the same paper, page 221, appears the following:

Ir. John S. Collins says: "I notice in last monthly, under the heading of 'The Comet Pear,' an opinion of the editor of the GARDExERs' IONTHLY which I do not consider correct. It would no doubt have been
proper for the owners of the farm on which the old pear tree had grown to have named it, if they had done so in a reasonable time and lext the name been known to the public. The person now most interested in
having the name of pear called 'Lawson,' states in his circulars and cata-
logues that the tree was probably Lamson the Elder,' and that the Lawsonn before the time of 'John secluded' it from the public. They neith family have always 'guardedly it to the public, although they neither raised the tree nor introduced

"I think there are sever generations. Comet is the proper name for the pear."

[Te have no desire to be the umpire in any personal quarrel between two business firms. The fact for an Editor is that two firms have two names for one thing, and the public will ask the Editor which name is.

The only facts for the Editor are simply these: The owner of a farm has a pear tree that came up on the land he owns. He gives a neighbor,
as a compliment, a fer grafts. After this the owner of the tree concludes 
to put the tree into commerce. He sells the whole stock in his possession to a nurseryman and tells the nurseryman its name is Lawson. Will it be contended that he shall be estopped from his undoubted right to call his own property what name he pleases, because a friend who received a few complimentary grafts chooses to forestall him by giving one of his own?

We are told that Mr. Lawson never "nttered a protest against" the extraordinary liberty of a stranger naming his own property without consulting him in any way.in the matter, and we do not know that he was called on to protest. If the owners "guardedly secluded" the tree from the public, they had the right to do so.

As an Editor, called on to decide this delicate question, we can only say that it appears that the owners of the tree have distributed the pear under the name of Lawson; they never consented to its being called anything but Lawson; and as, under Pomological rules, "the owner of a tree has the right to name it," we cannot see that we have any discretion but to accept Lawson as its legitimate name.-Ed. G. M.]

The editor of the Gardener's Monthly whose only desire is to promote the public good, has rendered valuable service to the community by lifting the veil to let the public see what was going on beneath. That instead of there being two pears so exactly alike in size, color, quality and time of ripening that no person could tell any difference; there was only the one pear propagated by two parties from the same original tree. And now offered for sale by two firms under two different names for the one thing "and the public will ask the editor which name is to be used," and he being entirely uninterested (excepting to keep the public informed of facts) has answered impartially and truly. If we had done the same thing it might not have been so well received, though in our first circular on the subject we did caution the public that "such a course would lead to confusion," which it has to some extent, already done; parties who had purchased of us the Lawson Pear trees afterwards without our knowledge, (which they had a perfect right to do) obtained the Comet so as to have both kinds. Parties residing in the far West, who knew nothing of the pear, except by the description and pictures sent out, have, after we had sent them Lawsons according to order, requested us to procure and send them Comets, as they wanted both. In such cases we felt in duty bound to inform them of the facts, that there was but the one Pear, which we had sent, that was being advertised and sold under two names, by two nursery firms, one of which was called LAWSON a yery old variety which we had sent; the other was called THE CONET NEW EARLY PEAR, they had both been propagated from the same original tree, now standing on a part of the estate of John Lawson the elder for which information we received hearty thanks in return. But our correspondence, (although somewliat laborious in the busy season) is limited, compared with the extensive circulation of a valuable journal like the Gardener's Monthly which is regarded as reliable authority on Horticulture and Pomology.

So let this vexed question, on which the three parties interested have had their say, remain settled in accordance with the late impartial, disinterested decision by high authority, after a full consideration of all the facts as presented by tae vat nemselves. 


\section{WHSTORY OF}

\section{The Original Lawson Pear Tree.}

This tree, supposed to be one hundred years old, and bears the impress of ages, is still healthy, growing in the cleft of a rock in the county of Ulster, State of New York, on the west bank of the Hudson River, two hundred and fifty feet above its level.

It is located on a part of the farm, which formerly belonged to John Lawson the elder, who first brought it into public notice by grafting and planting orchards of the young trees and sending the fruit to New York markets, where, on account of its earliness and great beauty, it attracted much attention, and was generally called Lawson's Early, Lawson's Beauty, and other prefixes to the owner's name, and sold readily at high prices, which increased as the Pear became better known.

It is the original stock from which all Pear trees of this variety have been grown.

It takes its name from John Lawson the elder, who during his lifetime, owned and occupied the plantation on which it grew and is yet standing.

At the decease of said Joln Lawson the elder, the farm with the original tree and those grown from it descended to his children, then to his grandchildren, who still own and occupy the premises, never having disposed of any trees, buds or scions with the privilege of propagation, for sale or distribution, as its early ripening, handsome color and fine appearance, rendered it a very profitable Pear for market, and solu last summer from $\$ 2.50$ to $\$ 4.00$ per one-half bushel ; yet the Lawsons generously gave to some neighbors and others, grafts to grow for their own use, but not for stle. So that the distribution of this valuable Early Pear was substantially restricted and kept within control of the Lawson family until recently, when for a valuable consideration the exclusive privilege to propagate and sell them to the public, under the name of LA WSON PEAR, was conveyed to William Parry by contract in writing signed by all the heirs.

And now the trees are offered for sale by nurserymen and will be widely distributed, and the Public can enjoy one of the most Beautiful and salable Early Market Pears yet introduced. Ripening with the little Doyenne D'ete, but equaling in size and earlier than Beaurre Giffard or Chambers Pears. It is to be regretted that some propagators have called this old variety by a new name and endeavor to disseminate it as a New Fruit, which may lead to confusion. Better apply to headquarters for the genuine stock, the name of which has never been changed, as we purchased the exclusive right to propagate and sell them under the true name of LAWSON PEAR; being the first sale and only one with exclusive privilege ever made of this valuable old variety.

The tree is a vigorous, upright grower, with clean, healthy foliage much resembling the Early Harvest and Jefferson in appearance and habit of growth. In an existence of ONE HUNDRED YEARS, it has never been affected with blight or other disease, is still healthy, and grafts cut from the original tree in 1883 have made rapid growth at POMONA NURSERIES, in BURLINGTON COUNTY, NEW JERSEY.

The daughter of John Lawson the elder, a lady well advanced in years, informs the writer of this, that she well remembers the original tree growing on her father's plantation more than fifty years ago, and it was an old tree then.

The young trees are rery productive and soon commence bearing. Fruit large, for an early pear, many specimens measure nine inches 
around and some more; firm and a good shipper; most beautiful crimson color on yellow ground, they seem to absorb and reflect the rays of the morning sun, and become more brilliant in clear dry weather. Flesh crisp, juicy and pleasant, though not best in quality, and should be used before getting over ripe, which in central New York is from the middle of July to the first of August, and when grown in Middle or Southern States where the season is several weeks earlier, and shipped to Northern markets their value as a profitable fruit must be apparent.

The Pear tree that has braved the winter's blast, and resisted insect enemies for a century past, vjelding bounteous crops of elegant fruit, deserves a place on the records of every horticultural society, and the good name of the family to whose care we are indebted for this beautiful pear, should always be attached to it, and not be exchanged for another merely to suit propagators.

Like the Seckel Pear tree, which is more than two hundred years old, and now standing within the limits of the city of Philadelphia. that takes its name from Lawrence Seckel, a former owner, who first introduced it to public notice on coming into possession of the farm on which it grew, although he found it full-grown, prolific bearing tree when he bought the property.

Still the name of Seckel has never been changer, nor should it.

Any fruit tree a century old or more, that has lived coeval with our Govermment, is deserving of tender regards and affectionate care.

But when like the Seckel and Lawson, they have so nobly and so long served man with their delicious and beautiful fruits, and founded the teeming families now representing them, and blessing the civilized people; have not the fathers of them all yeculiar claims upon the conservative care of all the Americans, and especially to a page on the records all pomological and fruit growers' societies.

These two desirable Pears must always rank ligh in their class, one for delicious flavor and the other for exquisite beauty.

Let them always bear the names of the men who first introduced them to public notice.

All good men desire to leave something when they depart from this world, as a constant reminder of the services rendered for the benefit of mankind. Let us hold them in grateful remembrances for the honor and glory that justly belongs to them for introducing new and valuable fruits like the Seckel and Lawson Pears for us to enjoy, after they have gone to the realms above from whose bourne no traveler has ever returned.

\section{CONTRACT FOR LAWSON PEAR TREES.}

Whereas John Lawson, the elder, in his lifetime owned and occupied a farm and plantation containing about one hundred and seventy acres, situate on the west shore of the Hudson river, in the county of Ulster, State of New York, whereon grew a natural pear tree, which produced an abundance of beautiful fruit of fair size and good quality, ripening in July, which sold well in market, commanding the highest price of any summer pear, and being a regular bearer was very profitable.

The original tree, still standing, is estimated to be more than ONE HUNDRED YEARS OLD, has never been affected with blight or other disease, is vigorous and healthy; grafts taken from it in 1883 have made rapid growth of more than four feet in length.

There have been several hundred of younger pear trees propagated by takiug suckers and grafts from it all of which were planted on the 
same plantation or tract of land, which descended at the decease of said John Lawson to his children and heirs-at-law, all of whom have lived upon and cultivated said premises ever since, without having sold or disposed of any land or pear trees, whereby the whole stock of said variety of Pear, called Lawson, is still in possession of said children and heirs-atlaw of said John Lawsor, deceased, excepting a fer grafts niven to some friends or neighbors for their own use, but not for sale or distribution; and they, the said children and heirs-at-law, baving full right, power and authority to dispose of the whole or any part of said stock of pear trees, have by the following agreement sold to William Parry fire thousand buds, with the EXCLUSIVE PRIVILEGE of propagating. selling and introducing them to others under the true name of LA IFSON Pears, as follows:

Marlborough, Ulster Co., N. Y.

Received of William Parry, of Parry, N. J.,-_-dollars in addition to a receipted bill for trees and nursery stock, in full payment for five thousand Buds of our LA WSON PEAR, with the EXCLUSIVE PRITILEGE of propagating, selling and introducing them to others under the true name of LAWSON PEAR, and we agree to furnish more buds of said varlety of Pear, if he should need them and we have thein to spare, And also agree not to sell to or grant the same privilege or authority to others, and the said William Parryfurther agrees to furnish us with one thousand trees, two years old, of LATWSON Pears, to be grown from buds that we send him free of charge, if we wish them.

(Signed) GEo. TV. LAwsor, Jxo. E. Lawson, SANDS HaTiLAND, EUGENE LAWSON,
MLari A. Havilaxd.

David SANDS,

Pheme SaNds,

J. LATSON.

\section{WE OFFER FOR}

\section{FAII'85 \& SPRINTG'86}

A Verp Nice Stock of Treas at the Following Rates:

Dormant Bud on 2 year French Pear Stocks,

1 Year 6 4 "6 6 6 6

2 "Heads, Top Grafts,

1 "Top Buds in heads of 2 year Kieffers,

2 "6 6 worked 66 4 66 6

Buds,

Dwarf 1 year,
Each Doz, 100

$\$ 1.00 \quad \$ 10.00 \quad \$ 75.00$

$\begin{array}{lll}2.00 & 20.00 \quad 150.00\end{array}$

$3.00 \quad 30.00$

$3.00 \quad 30.00$

5.00 to 7.50

$1.00 \quad 5.00$

$1.50 \quad 15.00$

WILLIAM PARRY,

PARRY P. O., NEW JERSEY. 


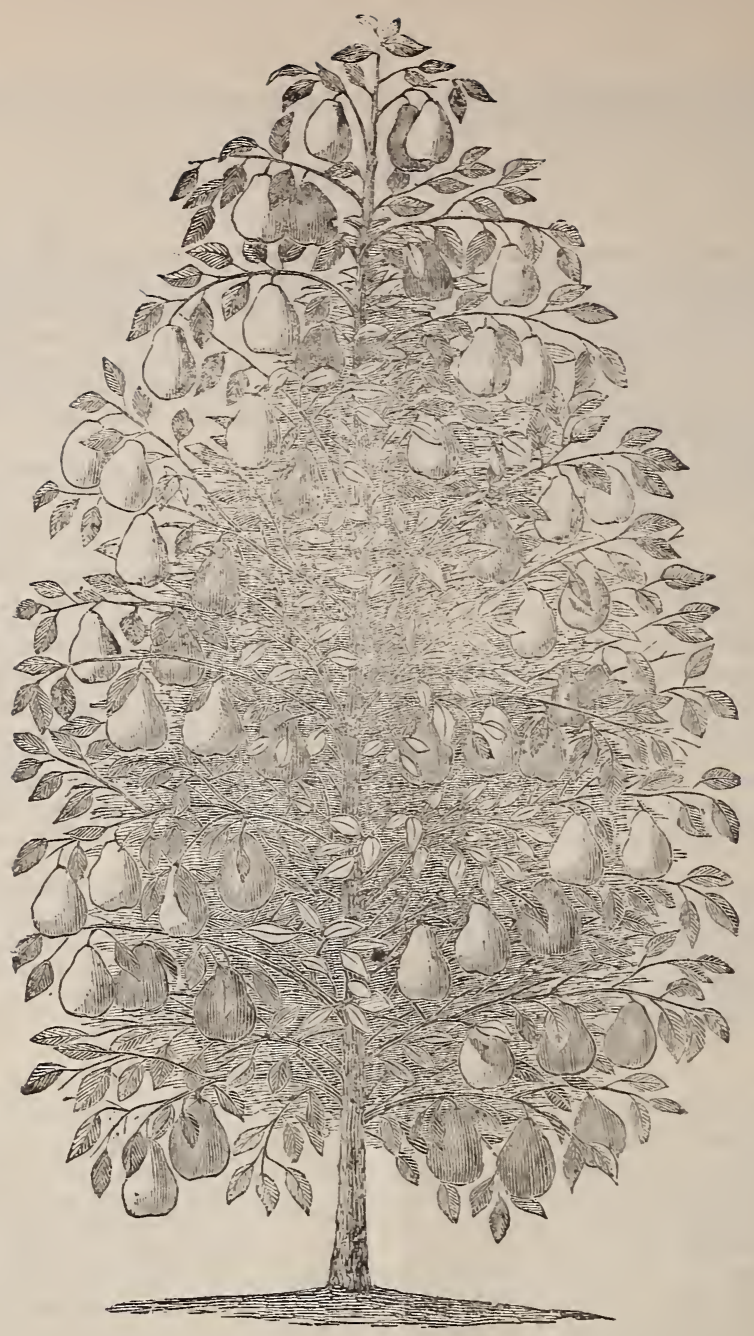

Propagated and For Sale try

\section{WILLIAM PARRY, PARRY N.J.}


very uniform in size; it colors up beautifully, giving a rich yellow appearance; it does not rot until very ripe, and remains firm at the core to the last. It ripens in October and Norember, and continuing on through the holidays, it has no competition in the market and sells readily at high prices. In Philadelphia last fall one grower found ready sale at $\$ 3.00$ per basket of half bushel each. Another retailed them at 50 to 75 cents per half peck, and fine selected specimens at $\mathbf{2 5}$ to 50 cents each. Another grower shipped to Worcester, Mass., and received, after deducting freights, commissions, cartage, etc., six dollars per bushel crate.

After another year's experience it is gratifying to us, the introducers, to state that the KIEFFER PEAR still heads the list as the most profitable late market variety. The trees continue thrifty, ramk and vigorous. In our twenty-five acres of Standards every individual tree is a perfect picture of luxuriant health, and are showing an abundance of handsome fruit.

\section{Our claims for the KIEFFER are}

That the tree is the strongest grower.

That it is the least liable to disease.

That it is the best adapted to all climates and conditions.

That it is the earliest bearer.

That it is the most productive.

'That it bears every year, having no oft years.

All of which being combined in one variety places it beyond competition.

Our trees are of unusually fine growth, and entirely free from quince sap.

In considering the requisites for a popular market pear, we will name the following:

First -A tree of vigorous growth, with luxuriant foliage.

Secondly - A tree that will come into bearing young and produce large quantities of fruit.

Thirdly-A fruit of good size, good quality and attractive appearance in market.

Fourthly-A fruit that, should one market be overstocked, can be shipped to whatever city will return the best prices.

Fifthly - A fruit that ripens at such a season that the market is bare, which will guarantee good prices.

The above all being united in Kieffer's Hybrid, it cannot fail to become a general favorite.

In our nursery rows our four-year-olds are producing one-half peck or more fruit per tree, and many of the three-year-olds are bending under their heavy crops of fruit. Our five and six-year-olds in orchard last fall produced two to three baskets per tree, which sold in market at four to seven dollars per bushel.

\section{QUALITY AND APPEARANCE.}

To get the best quality and most delicate flavor, Kieffer's Hybrid, like most pears, should not be allowed to hang on the tree until it falls off of its own weight, but should be gathered when fully grown, and ripened in the house, when, like the Bartlett, it will color up nicely, which, with its rich, glowing red cheek, combined with the delicious perfume, gives it attractions with which but few can be compared.

Upon our first introduction of this pear, and after offering it for sale, the Editor, American Agriculturist, says : "We have not, in a long time, seen a fruit that appears to unite so many elements of popularity as Kieffer's Hybrid. The tree is a strong and vigorous grower, bears early, is very productive and apparently as free from disease as the Sand Pear, which is one of its parents." And in our comparing it with Duchesse D'Angouleme, he still further states: "That we have under-estimated its quality, as his recollection was that it has a refreshing briskness that the Duchesse has not."

Thomas Meehan, of Gardener's Monthly, says : I have eaten fruit of Kieffer's Hybrid that was equal in luscious richness to any pear I ever ate. I regard it as the most wonderful production of the age.

At the International Exhibition, held in Philadelphia in 1876 , by the U. S. Centennial Commission, the prize medal and certificate of award was given to P. Kieffer for this variety. The committee reported as follows: "He exhibits a HYbrid PEAR of ReMarkable ExCELlence, between the common pear of cultivation and the Chinese Sand Pear, giving promise of a NEW RACE OF GREAT EXCELLENCE.

\section{The Pennsylvania Fruit Growers' Society Reports :}

"Of the Seedings of China Sand Pear it seems proper to state that Kieffer's Hybrid has fully held its own the past year, and so far has proved to be all that was claimed for it, in quality as well as in fruitfulness, vigor of growth and freedom from disease."

And the fall, I88I, we had on exhibition, at Burlington County Agricultural Society, held at Mt. Holly, N. J., trees I, 2, 3 and 4 years old, the latter showing 17 handsome pears, measuring from 8 to 12 inches around. We were awarded a special medal for this variety.

And whenever exhibited at State or county fairs, it has always been awarded the highest premium by the Society, and received the marked attention and special admiration of the visitors. 
In addition to the many Medals, Prizes, Honorable Mentions, Favorable Notices, \&c.. which we have received from the various Exhibitions and Horticultural Societies, we were awarded A SPECIAL PREMIUM for our Exhibit of KIEFFER'S HYBRID PEARS. at the American Pomological Convention, held in connection with the Penn. Horticultural Society, Phila., Sept., 1883 , showing two four year old trees, dug from Nursery Rows, and bearing forty to fifty Pears each.

At the WORLD's EXPOSITION at New Orleans, La., 1885, we were also awarded First PRENIUMS for our Kieffer Pears, fresh and canned, and for our exhibit of ORIENTAL and Hybrid Pear Trees.

As a CANNING Pear, Kieffer's Hybrid has no equal. Heretofore the canning of Pears has been of little interest compared with that of Peaches and Tomatoes, from the fact that Bartlet:, the best variety canned, ripens at a season that the canners are running to their fullest capacity on Peaches and Tomatoes, which require to be handled very quickly, and to work the Bartletts would be at the expense of the other equally perishable fruits.

Kieffer's Hybrid has all the desirable canning properties of the Bartlett, and, in addition, a preference of season. Ripening in October and November, after Peaches and Tomatoes are out of the market, the canners can give it their entire attention and extend their season another month.

I sent a small quantity of Kieffer's Hybrid pears to an extensive canner to have put up for us and wrote him that we had twenty-five acres in them and would soon have a large amount for sale, to which he replied:

"I have put up those pears in tin; they are very fine indeed; they beat the California Pear and will out sell them. We may want to buy thy entire crop. I find the flavor a little on the quince, which is no objection, for that flavor is very delicious. I am of opinion they will be a success ; if so, we can use all thee can grow."

It is very gratifying to us to be able to state to our friends and patrons that the Kieffer has fully maintained the exalted reputation heretofore enjoyed. Its success being universal, the reports received from the various sections of the Unised States being most flattering, succeeding admirably upon the Bleak Plains of the Northwest, the mild temperature of its Native State, or under the scorching rays of the Sunny South. It appears to be peculiarly adapted to a wide range of country, and a variety of soils and localities; so that in sections where our choice dessert fruits have been unknown, the inhabitants may hope to grow their own Kieffer Pears and enjoy the luxuries of more favored climes, though it will attain its greatest perfection in long seasons and warm climate.

Although upon our first acquaintance with this fruit we recognized its sterling merits and rare good qualities, yet our confidence continues to strengthen as we gain experience in it.

As Fruit Growers are aware of the many impositions practiced by unprincipled dealers in newand rare fruits, and can appreciate the value of a genuine article over that of doubtful purity, I take this occasion to state we have Twenty-five Acres in orchard, containing Five Thousand Kieffer's HybRid Pear Trees, a large proportion in fruiting, among which are the original trees, procured from the originator from which we are propagating our stock for sale.

And although our stock has been carefully grown from healthy standards, the advantages of which our customers will not fail to realize over those propagated from dwarfs; yet as our supply is large and complete, we will not be undersold, and should they be offered by any respon. sible dealer or grower at rates below those of this Catalogue, we will furnish at the same.

\section{THIS RULE may also apply to GRAPE VINES or ANY OTHER STOCK we} quote.

\section{CAUTION.}

\section{Quince Sap Poison to Kieffer and other Oriental and Hybid Pears.}

As we have the honor of introducing Kieffer's Hybrid we are naturally anxious that its high character for vigor of growth and freedom from disease may be maintained; and that our reputation as well as that of the pear may not suffer, we therefore CAUTION DEALERS and PLANTERS against using buds, or trees propagated from buds taken from Dwarfs grown on Quince; or from Standards that have been so propagated, or, in short, not to accept trees whose ancestry can be traced to trees having any Quince Sap in them; as, like Peach buds taken from trees affected with the yellows, the poison or disease is transmitted to the young stock, its vitality impaired and although it may appear healthy for a time it is rendered liable to blight and prematurely: dies.

We are aware that many nurserymen, not realizing the damaging results, are offering such buds and trees propagated from such buds at very low rates.

We have tested, to our satisfaction, nearly all the Oriental and Hybrid Pears on Quince and find none of them succeed, LeConte and the Sand Pears doing even worse, if possible, than Kieffer, and from our experience with Kieffer, we should consider trees of any of the above varieties, or any of this RACE of PEARS, if tainted with Quince Sap, worthless and dear at any price, while with the pure Standards we can freely endorse all that has heretofore been saicl in their favor. Of the twenty-five acres we have in orchard, containing 5,000 trees, we have never seen the slightest evidence of blight on the Standards; the oricinal trees, procureil from Mr. Kieffer, from which we are propagating our stock for sale, last fall were heavily laden 
with immense loads of fruit, one hundred bushels or more, which sold readily in the Philacie! phia and New York markets at four to six dollars per bushel, and were the wonder and admira. tion of the many visitors who called to see them; while the DwARFS are dying by the hundreds, yet many nurserymen have used thousands of buds taken from Dwarfs, and the trees grown therefrom are now being offered at low rates and consequently the trees being liable to blight, the reputation of the Kieffer will suffer and the hopes of the planter be disappointed.

The editor of the American Agriculturist states "It seems a well-established fact that the Quince is poisonous to trees containing an admixture of the Chinese Sand Pears. Those who propose to plant these Hybrid trees should stipulate that they shall be free from any contamination with the Quince." Prof. Meehan, of Gardener's Monthly, does not confine it to the Oriental and Hybrid Pears; but says "propagation should never be from trees grown on Quince in any case, as they will partake of the low vital power engendered by the Quince, and are rendered more liable to disease."

\section{PRICES OF PEARS.}

\section{ORIENTAL PEARS.}

\section{SHA LEA-Chinese Sand Pears.}

Nos. 23, I404, 1405, 1407, I year, 2 to 4 feet 2 years, 4 to 6 feet

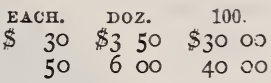

SUET LEA-Chinese snow Pear.

I year, 2 to 4 feet

\section{JAPAN SAND PEARS.}

Daimyo, Madame Von Seibold, 2 to 4 feet, I year,

$40 \quad 400 \quad 3000$ Mikado, Cincincis, Cincincis Seedling, $\} 4$ to 6 feet, 2 year, - $50 \quad 5004000$

\section{SANDWICH ISLAND PEAR.}

Hawaii, I year, 2 to 4 feet,

2 years, 4 to 6 feet,

\section{HYBRIDS-Sha Lea.}

\section{KIEFFER STANDARD.}

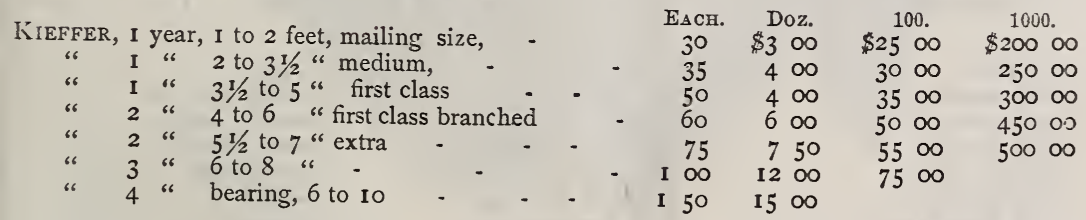

$\begin{array}{rrr}50 & 500 \\ 100 & 1000\end{array}$

DWARF.

2 years, first class,

year, 2 to 4 teet 2 years, 4 to 6 feet

I year, 2 to 4 feet, 2 years, 4 to 6 feet

I year $3 \frac{1}{2}-4 \frac{1}{2}$ feet,
GARBER STANDARD.

\section{COCKLIN.}

\section{DUCHESSE HYBRID.}

HIBRID.-Suet Lea. LE CONTE STANDARD.

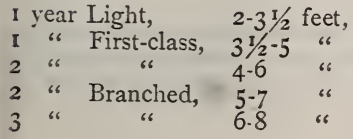

I 001000 


\section{SMITH'S.}

I year, $21 / 2$ to $31 / 2$ feet

2 " 4 to 6 feet

I year, $2 \mathrm{x} / 2-4$ feet

2 years, 4 to 6 feet,

\section{EARLY HARVEST.}

The ORIENTAL I-ears-Chinese, Japan and Sandwich Islands, are all for kitchen use, excellent for cooking, are hardy and beautiful ornamental trees. The Hybrids inherit the hardiness, beauty and luxuriance of the Orientals combined, with the delicious qualities of our cultivated pears.

Buds of toregoing Pears at 25 cts. per duz.; $\$ 1.00$ per 100 by mail.

Small trees of same by mail at rate per single tree.

By EXPRESS ;

Kieffer Hybrid cuttings, 12 to 15 in. $\$ 1.00$ per $100, \$ 7.50$ per 1000.

Le Conte " " " " 1.00 " 7.50 "

Champion Quince, cuttings, 7 to 8 in. 1.00 " 7.50 "

\section{CHERRIES.}

First-class

Light

Black Eagle,

Downer's Red,

Early Purple Guigne,

Elton, Belle d'Orleans

Gov. Wood,

Rockport Biggarreau,

Black Tartarian,

\section{SELECT LIST}

Large Montmorency, Dye House,

Carnation,

Early Richmond,

Belle d'Choice,

Belle Magnifique,
EACH. DOZ.

$40 \quad 400$

$60 \quad 500$

$\begin{array}{cccc}\text { EACH. } & \text { DOZ. } & 100 . \\ 40 & 400 & 3000 \\ 75 & 7 & 50 & 6000\end{array}$
PEACHES.
No. I, Extra, 5 to 6 teet,
No. I, First-class, 4 to 5 feet,
No. 2 , Good, $21 / 2$ to 4 feet,
In dormant bud,
Waterloo,
Early Alexander
Early Beatrice,
Early Rivers,
Mountain Rose,
Troth's Early,
Large Early York,
Crawford's Early,
Foster,
Wheatland,

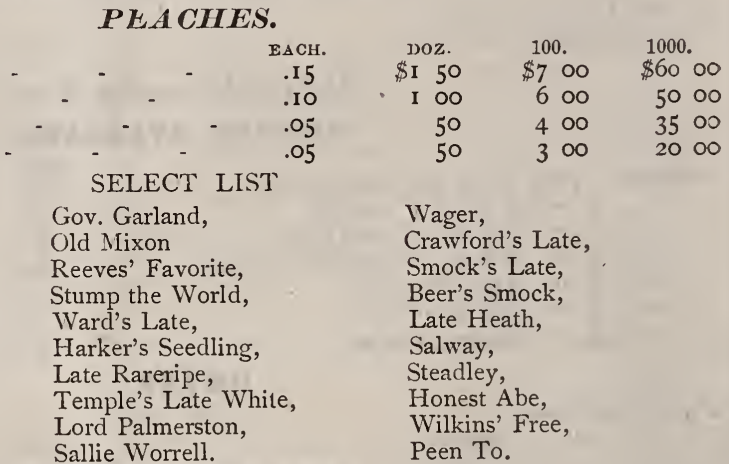

Empress Eugenie,

May Duke,

June Duke,

Ox Heart,

Yellow Spanish,

Olivet.

Having many inquiries for Peach trees by mail we can only send them that way in dormant bull, to which price add 5 cents each for postage.

\section{PLUMS.}

First-Class, 4 to 6 feet,

Coe's Golden Drop,

Imperial Gage,

Washington,

\section{SELECT LIST.}

Jefferson,

Richland,

Green Gage, 
PRICES-except where noted, twenty-five cents each

caddo Chief.- "The earliest of all Plums, ripening with Early Richmond Cherry, largt, good, firm, bright dark red."

Early Red.- " Medium sizes, pink, nearly free, small seed, firm, very fine quality."

Yellow Transparent.-." "Clear yellow, oblong, excellent in quality and very productive."

Wild Goose. "Large rich crimson, very productive and profitable." Blackman.-- "Resembling a peach tree so nearly as to give the supposition that it may be a

Forest Gurden.-_" Large and good quality."

Inclian Chief._- " Round, bright red, size of Wild Goose, five to six weeks later.'

Golden Beauty.-_ "Round, large as Wild Goose, rich golden yellow, very firm, small seed, nearly free, excellent in quality, immensely productive, very late and valuable."

\section{MARIANNA PLUM.}

An accidental seedling of Wild Goose, rapid grower, fruit round, large as Wild Goose, excellent, deep bright red, stone small, hangs on tree well, two to three weeks earlier than Wild Goose, as free from curculio as any variety known, very prolific. Price, $\$$ I.00 each.

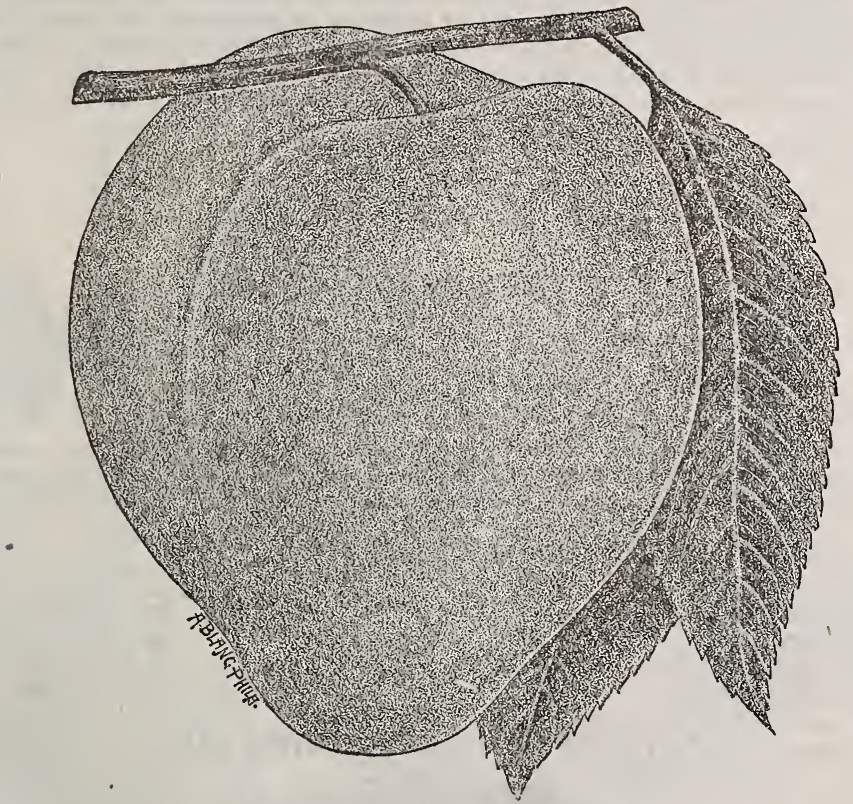

KELSEY'S JAPAN PLUM.

Another novelty from Japan is Kelsey's Japan Plum, which has proven hardy with us. It is a good grower, and free from disease in every form; fruit of large size and of finest texture; considered the finest plum grown. Price, $\$ 1$.00 each; $\$$ I 0.00 per dozen; $\$ 75.00$ per Ioo.

Prunus Simoni.-Apricot Plum. This new plum, a native of northern China, is believed to be the most valuable new fruit introduced for many years, being hardy as far north as central Iowa and Nebraska, and in protected situations even farther. Its fruits are very pretty, with very short stem, size of Orleans Plum, with brick red or dark cinnabar color. The flesh shows a fine apricot yellow, firm, and has a peculiar aromatic flavor not found in the plums we
cultivate. Price, \$1.00 each; \$10.00 per dozen.

Prunius Pissardi.-A new purple leaved plum from Persia, very ornamental. The fruit is medium sized, nearly round, dark purple, pulpy flesh, very sweet, juicy and good. It is said to be unusually exempt from the attacks of curculio. Price, $\$$ I.00 each; $\$$ IO.00 per dozen.

\section{QUINCES.}

Hong-Kong or China (very large fruit),

Orange,

Champion, I year,

Champion, 2 years,

Meech's Prolific, I year,

$\begin{array}{lll}- & - & - \\ - & - & - \\ - & - & - \\ - & - & - \\ - & - & -\end{array}$

\begin{tabular}{rrrr}
\multicolumn{2}{c}{ EACH. } & DOZ. & 100. \\
$\$$ & 50 & $\$ 500$ & $\$ 4000$ \\
25 & 250 & 2000 \\
& 25 & 250 & 2000 \\
40 & 400 & 3000 \\
I 50 & I 500 &
\end{tabular}




\section{CHAMPION QUINCE.}

The fruit is very large, averaging nearly twice as large as the Orange Quince growing beside it, and, in productiveness, far surpassing that variety. Young trees only two years from bud, and first season after transplanting, are often loaded with fruit, and young as they are, the fruit upon them often weighs a pound and measures a foot around. In form it is intermediate between the well-known apple-shaped and pear shaped quince, with the stem inserted at the base of usually prominent lips. The skin strongly russetted for ai short distance around the stem; below, a lively yellow color, giving it a beautiful appearance. Its flesh cooks as tender as the apple and without hard spots or cores, as is often found in common quinces; in flavor it is most delicious, giving a very strong, exquisite quince taste and odor that is most refreshing.

Its season of ripening is about two weeks later than the Orange Quince; its keeping qualities the best of all the quinces; keeps in ordinary cellars without any special care into January. In growth it is very strong, stout and rugged, ripening its wood to the terminal bud.

\section{RUSSIAN APRICOTS.}

The Russian Apricot is claimed to be in every way superior to the American varieties in early bearing and quality of fruit, as well as hardiness of trees, and free from all disease, worms and insects, that have been so destructive to trees and fruit of the Peach and Plum.

In extremely cold locations, where the mercury falls to $40^{\circ}$ below zero, the Russian Apricots have passed through the winter safely, while the Americans by their side have been killed to the ground.

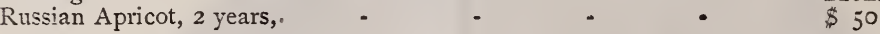

American Apricots, ass'd, Nectarines

\section{PERSIMIMONS.}

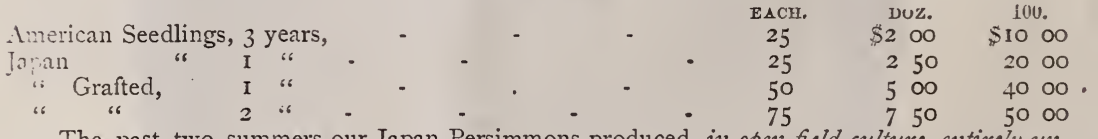

The past two summers our Japan Persimmons produced, in open field culture, entirely unnprotected, large, handsome specimens of fruit, measuring 6 to 9 inches around, which fully matured and were equal in beauty and lusciousness to the glowing descriptions we have had of them.

\section{MULBERRIES.}

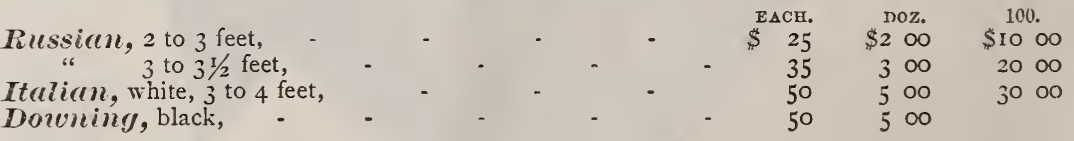

JAPANESE SWEET CHESTNUT.

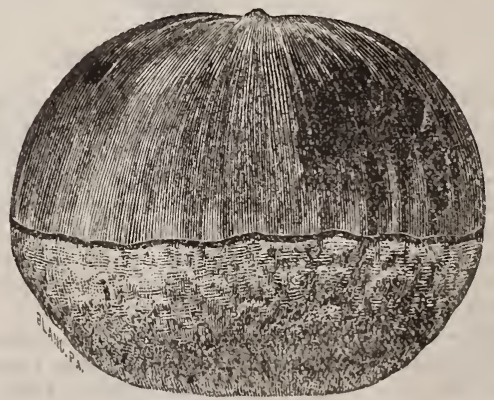

Of the novelties recently from Japan, nothing is more deserving of cultivation than the Jaranese Sweet Chestnut. It is quite distinct from the European varieties, being more hardy, anil the fruit of superior flavor and sweetness; the leaf is long and narrow, like a peach leaf, deeply serrated at the edge; comes in bearing very young, the first in this country, bearing at four years from the seed; fruit larger than the largest of the European sorts; shape, flavor and color like our best native. They have grown here at PONONA NURSERIES the size represented above, on trees three years old. 
Japan Chestnut, 2 to 3 feet, I year grafted,

is 3 to 4 " 2 "

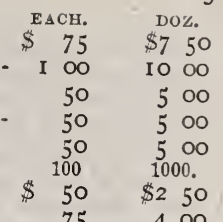
3 " seedling,

Spanish Chestnut, 4 to 6 years,

PRÆPARTURIENSIS, or Dwarf English Walnut,

OSAGE ORANGE, I year, strong,

DIAMOND WILLOW, salix cordata var. vestita. Ex-Governor Furnas states : "Experience
demonstrates it as desirable, demonstrates it as desirable, almost, for underground uses, posts, \&c., as red cedar." And as it grows rapidly is valuable for timber, fencing, \&c.

Price, I year old, 3 to 4 feet,

Price, 2 " - $\quad \$ 25$

Price cuttings, $\mathrm{I} 2$ in.,

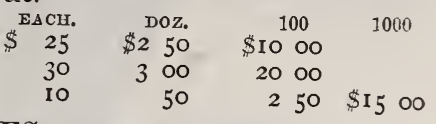

\section{STRA WBERRIES.}

We endeavor to handle our plants in the rery best manner. They are carefully cleaned, the roots straightened and neatly tied in bundles of fifty each. In furnishing orders we take up the beds solid, and the purchaser receives the strongest and best plants made during the sealast efforts of the runners, and apt to be small and weak.

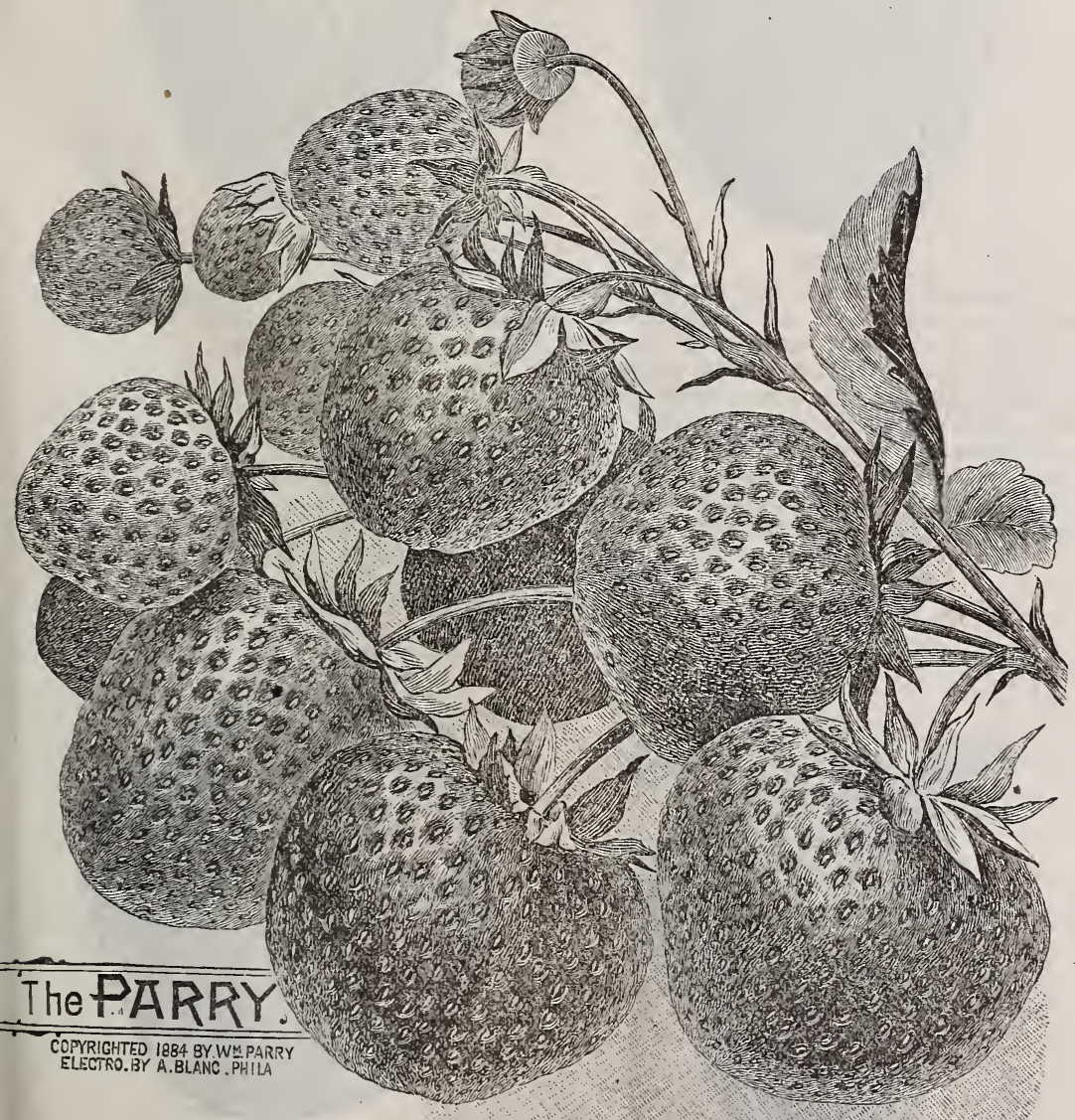

THE PARRY STRAWBERRY.

Awarded the first premium for three years at the strawberry fair of the Moorestown Agricultural and Industrial Society as the best variety on exhibition, and has again surpassed all 
others, over 50 best varieties, at Posiona Nurseries, and received three more first premiums and two more special awards at Moorestown, Vineland and New York Strawberry shows. Also the first premium and sweepstake prize over all other new varieties at Providence, R. I.

A seedling of Jersey Queen, produced by me in I880; and may be described as follows: Plant, vigorous, clean foliage; berries, uniformly large in size, obtuse conic, bright glossy scarlet, firm and of best quality-ripening all over at once; blossoms hermaphrodite or perfect. The Jersey Queen was considered by its originator, E. W. Durand, and by its disseminator, Peter Henderson, and others, to combine more excellent qualities than any other strawberry. The Parry possesses all the good qualities of the mother parent, Jersey Queen, with the addition of a perfect blossom, ensuring productiveness under all circumstances, and is believed to be a variety or infinite value.

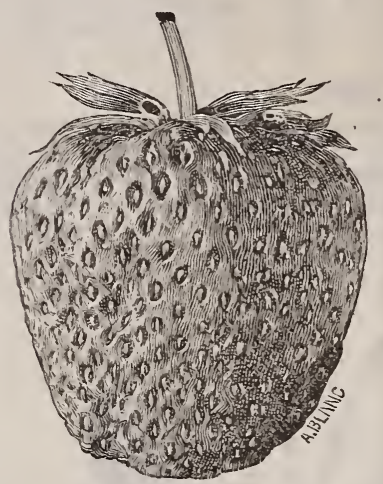

LIDA.

A promising seedling, raised from E. IV. Dusand's large strawberry, the King Cluster, in ISSO. It is a pistillate variety, large size, very productive, bright red color, heart shape, regular and uniform in appearance, ripens medium season, firm in flesh, a good shipper and excelient quality. Producing as many berries as Crescent and much larger in size. A limited number of plants for sale Spring, I886, at \$1.00 each; \$10.00 per dozen; \$75.00 per 100 .

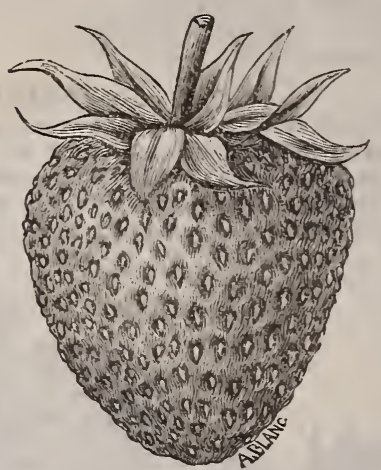

LEGAL TENDER. (P.)

LEGAL TEXDER: The fruit is from medium to large, very uniform in shape, firm, rich, crimson color, delicious quality and very productive.--Blossoms Pistillate.

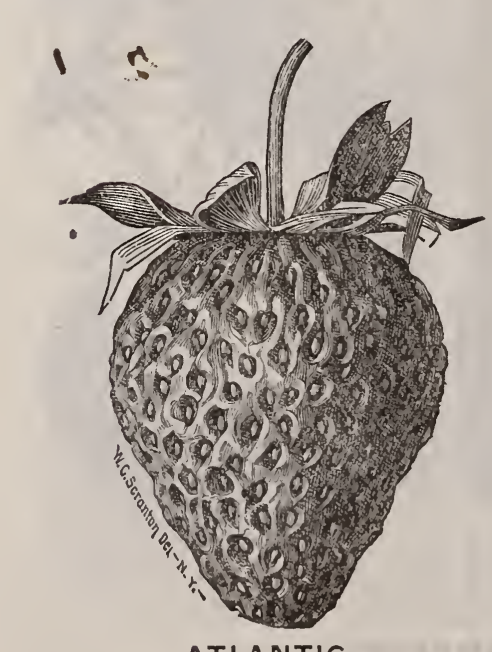

ATLANTIC.

The fruit is of rich, glossy color, wery firm, bright colored.

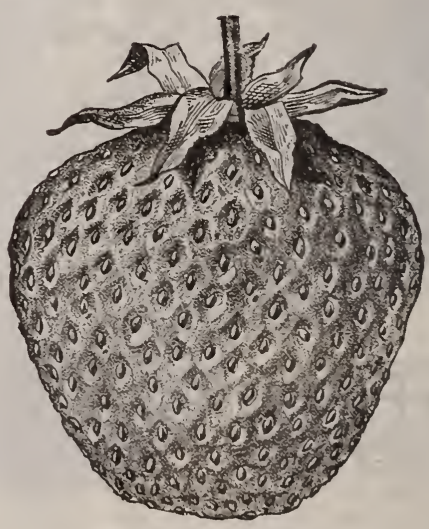

MRS. GARFIELD.

A seedling from Crescent with perfect blossom, vigorous, productive, early, firm, and strong grower, very productive and late. 


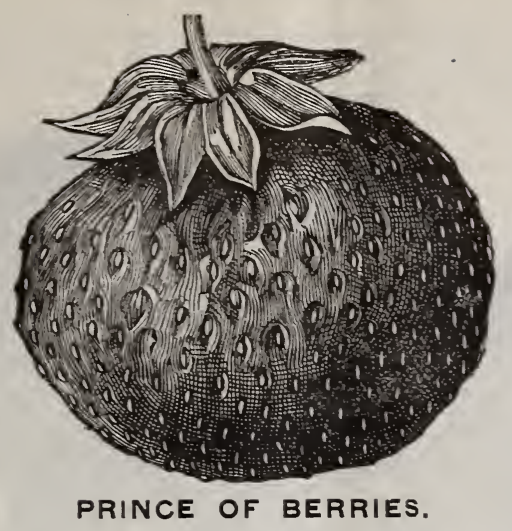

PRICE OF STRAWBERRY PLANTS.

We can supply plants during August at the rate per dozen; during September at dozen and 100 rates; during October and November at dozen, 100 and $\mathrm{I}, 000$ rates.

The prices herein named are for layer plants. By giving us two weeks' notice, we can furnish pot-grown plants during August, September and October, at an additional cost of 25 cents per dozen; \$I.50 per 100 .

\begin{tabular}{|c|c|c|c|c|c|c|c|c|c|}
\hline Agriculturist, & $\begin{array}{r}\text { Doz. } \\
\$ 25\end{array}$ & $\$$ & $\begin{array}{r}100 . \\
50\end{array}$ & $\begin{array}{r}1000 . \\
\$ 300\end{array}$ & Jewell. (p) & $\begin{array}{l}\text { Doz. } \\
200\end{array}$ & & $\begin{array}{r}100 . \\
\infty\end{array}$ & 1000. \\
\hline Albany Wilson, & 25 & & 50 & 250 & Jucunda, & 50 & & 50 & 8 oc \\
\hline Atlantic, & 50 & I & $\infty$ & 750 & Jumbo, & 50 & I & oo & \\
\hline Bidwell, & 25 & & 50 & 250 & Kentucky, & 25 & & 50 & \\
\hline Big Bob, (p) & 25 & & 50 & 250 & Legal Tender, (p) & 50 & I & $\infty$ & \\
\hline Jo & 25 & & 50 & 250 & Longfellow, & 50 & & 75 & \\
\hline (p) & 30 & & 50 & 300 & May King, & 50 & 2 & $\infty$ & IO \\
\hline ng, & 25 & & 50 & 250 & Manchester, (p) & 50 & & 50 & \\
\hline Cinder & 30 & & 50 & 300 & $\mathrm{Mir}$ & 30 & I & $\infty$ & \\
\hline it Queen, & 50 & I & $\infty$ & 500 & & 30 & & 75 & \\
\hline Corn & 50 & I & 50 & 1000 & rfield, & 50 & I & $\infty$ & \\
\hline Cres & 25 & & 50 & 250 & ernon, & 25 & & 50 & \\
\hline (p) & 25 & & 50 & 250 & PERB & 25 & & 50 & \\
\hline Triumph, & 30 & & 75 & 300 & $\mathrm{Clad}$, & 25 & & 50 & \\
\hline DNE, (p) & 50 & I & $\infty$ & 400 & $\mathrm{PA}$ & 75 & 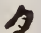 & $\infty$ & 85 \\
\hline רa & 50 & I & $\infty$ & $5 \infty 0$ & & 25 & & 50 & 3 \\
\hline Fino & 40 & I & $\infty$ & $3 \infty$ & 1 & 25 & & 50 & \\
\hline & 30 & & 75 & $25^{0}$ & Prince of Berries, & 50 & I & 50 & I0 \\
\hline an, & 50 & I & $\infty$ & 500 & & 25 & & 50 & \\
\hline (2) & I 50 & IO & $\infty$ & & Vin & 25 & & 50 & \\
\hline & 30 & & 75 & 400 & & 30 & & 75 & \\
\hline Vick, & 25 & & 50 & 250 & Windsor Chief, & 30 & & 50 & \\
\hline Que & & & 50 & & & & & & \\
\hline
\end{tabular}

Special price for large quantities of Parry, May King, Atlantic and others.

Among the best early varieties we would name Parry, Bidwell, Crescent, Warren, May King, Crystal City and Old Iron Clad.

Medium-Daniel Boone, Legal Tender, Cumberland Triumph, Sharpless, Mrs. Garfield.

Late-Kentucky, Longfellow, Glendale, Mt. Ternon, Manchester, Atlantic and Cornelia. 


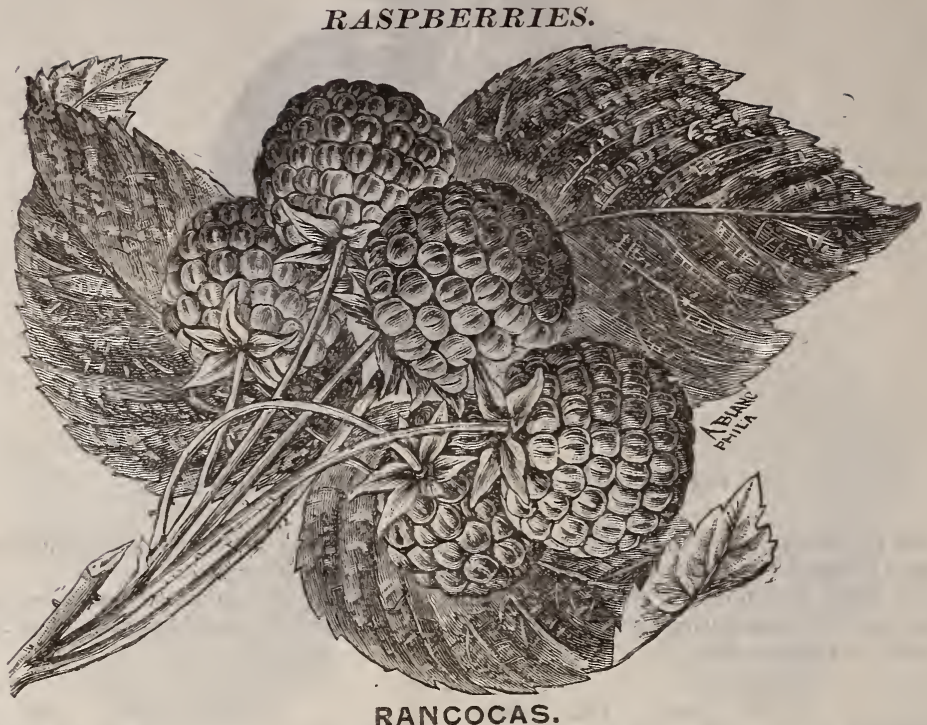

Very early, very hardy, very vigorous and very productive; bright red color and excellent shipper. Valuable for market.

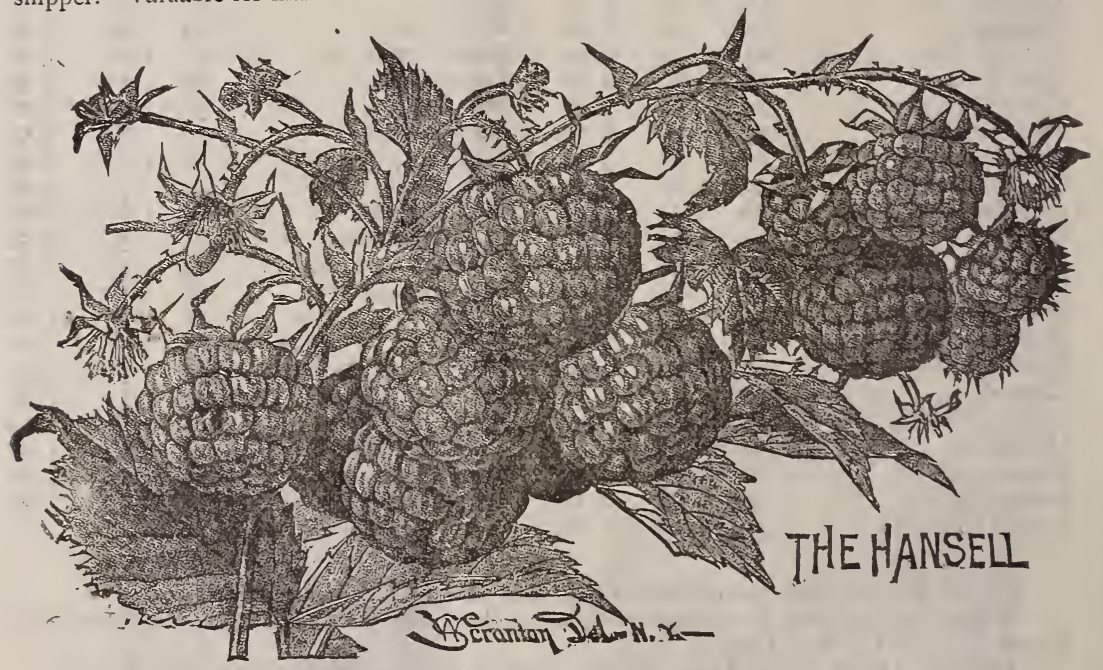

THE HANSELL RASPBERRY.

Description as given by the introducer.

"Originated by the late James S. Hansell, in Burlington county, N. J.; has been fully examined by the leading small fruit growers of New Jersey and adjoining States, and, owing to its extreme earliness and other good qualities, unanimously pronounced 'the most desirable and valuable raspberry in existence.' It is believed to be as hardy as that iron-clad varietythe Turner; is a good grower and productive; while the fruit is of the brightest crimson, of superior quality, good size, and, above all, very firm, having been shipped four hundred miles in good condition. This is uniting a vast amount in a single variety certainly, particularly when it is remembered that it ripens, as it does, far in advance of all other kinds. It ripened its first berries in $\mathbf{I} 880$ on June $4^{\text {th }}$, and on June $\mathbf{I} \mathbf{I}$ th, $\mathbf{I} S S_{I}$. The season of $\mathbf{I} 88_{j}$, when everything was 
nearly two weeks later than usual, it was ripe on June 20th, and afforded a good picking on the $25^{\text {th }}$-in all instances fully ten days ahead of the Brandywine, by the side of it, with the same treatment. Of course such a berry would command a high price in market, but this is not conjecture, as it has for the past three years-in fact ever since shipped for sale-sold at from twenty to twenty-five cents per pint, wholesale."

"Resolved, That it is the sense of this meeting that this is the earliest Raspberry so far known; further, it is of a bright red color, of fine snape, and of great firmness."

Unanimously adopted.- Report of meeting on grounds of originator, June $27,1882$.

Although the $\boldsymbol{H} \boldsymbol{N} \boldsymbol{N} \boldsymbol{S E L L}$ was highly extolled upon its first introduction and endorsed by the leading horticulturists, as the "best early Raspberry," it has fully sustained all that was said in its favor, which is not common with new fruits, and the past season has surpassed even the fondest anticipations of the introducer and proven more than he claimed for it, being much arger than represented.

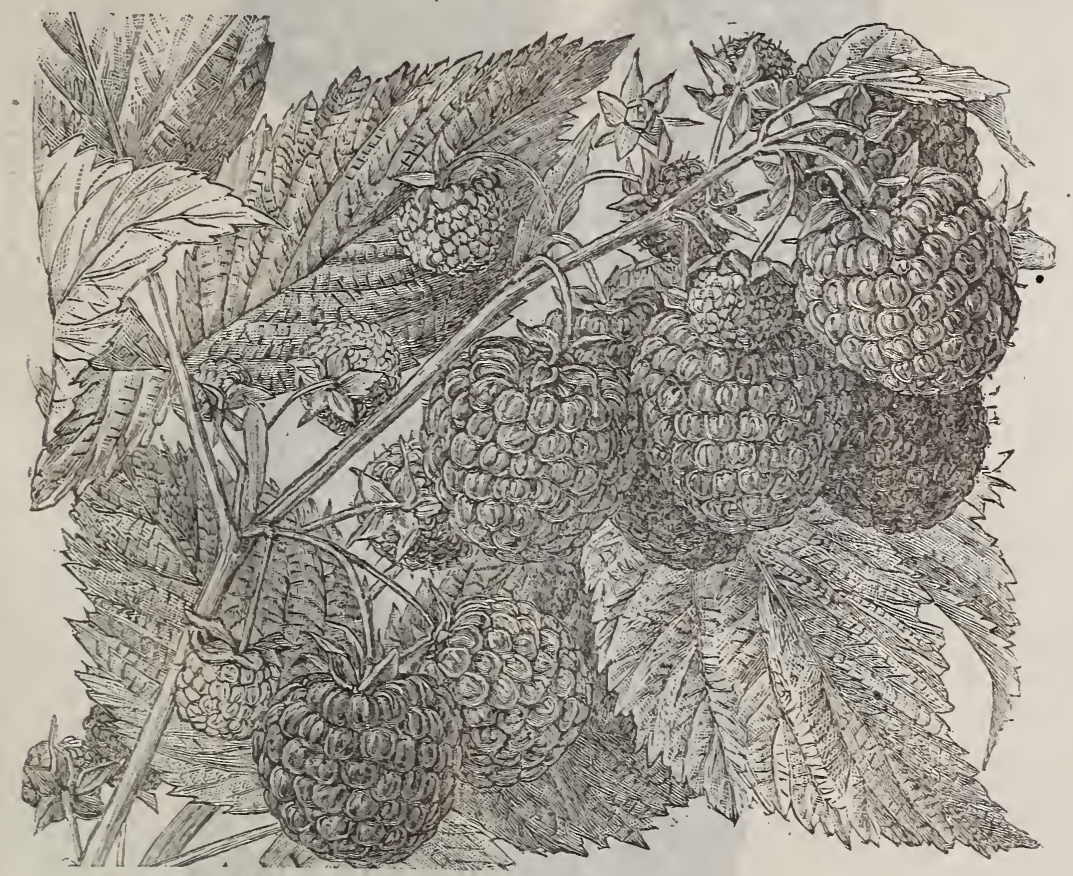

\section{MARLBORO RASPBERRY.} earlier.

The IIUrboro is claimed to be equal to the Cuthbert in every respect, and two weeks

We have a very superior stock of this very valuable raspberry, which has proven at Pomona Nurseries, on light ground, to be all the originator claimed for it on its natural soil. RED

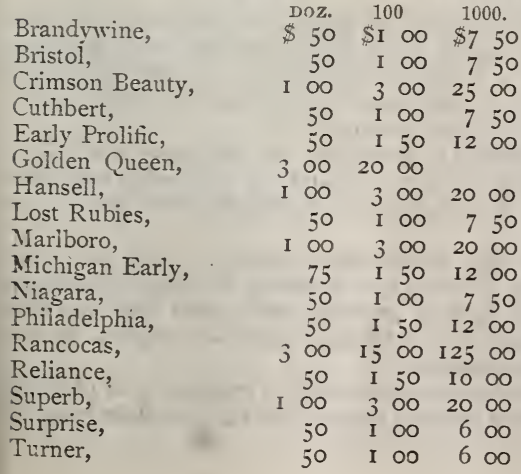

Canada, black,

Caroline, yellow,

Davison's

Thornless, black,

Doolittle,

Florence, yellow,

Gregg, black,

Hoosier, black,

Hopkins', black,

Mam. Cluster, black,

Nemaha,

New Rochelle, red,

Ohio, black,

Shaffer's, red,

Souhegan, black,

Tyler,
CAPS.

\begin{tabular}{|c|c|c|c|}
\hline Doz. & 100 & & 1000 \\
\hline & & $\infty$ & $\$ S \circ$ \\
\hline & & ०o & \\
\hline 50 & & 50 & 1000 \\
\hline 50 & I & 50 & IO 00 \\
\hline 50 & I & 50 & 1000 \\
\hline 50 & I & 50 & I0 00 \\
\hline 75 & 2 & $\infty$ & I5 00 \\
\hline 75 & I & $5^{\circ}$ & 12 \\
\hline 50 & I & 50 & I0 00 \\
\hline$\infty$ & IO & $\infty$ & \\
\hline 50 & I & 50 & 100 \\
\hline 50 & I & 50 & 100 \\
\hline 50 & 3 & 00 & 25 \\
\hline $5^{\circ}$ & I & $5^{\circ}$ & 1000 \\
\hline & & $\infty$ & I 2 \\
\hline
\end{tabular}


BLACK BERRIES.

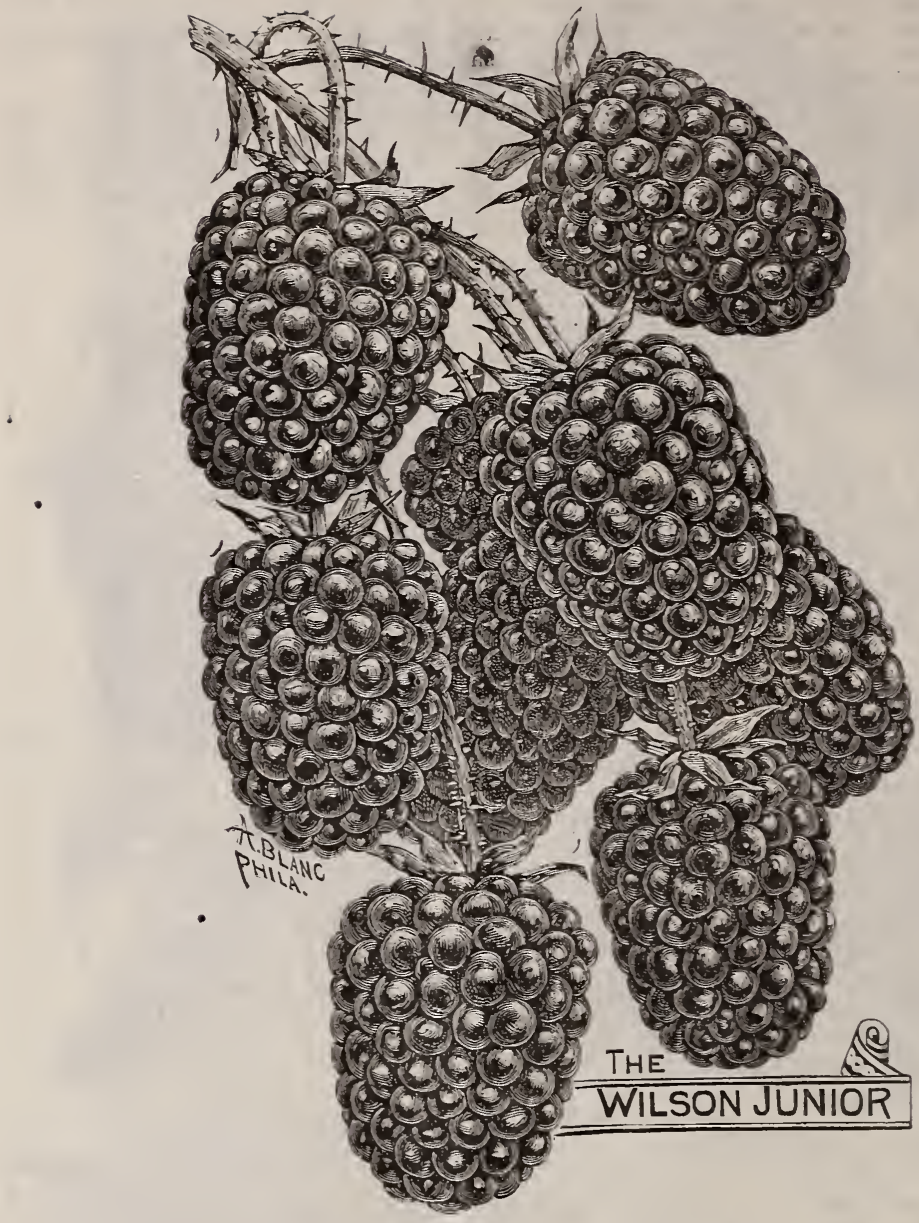

PEDIGREE BLACKBERRY, WILSON, JR.

This new and improved variety, now attracting so much attention, was raised from the seed of selected fruit of the Old Wilson Early-the largest, handsomest, best and most profitable blackberry known at the time of its discovery, in or about the year I 854, by John Wilson, of Burlington county, N. J., and produced more bushels and more dollars than any other blackberry sent to New York or Philadelphia in the last quarter century.

The principal blackberries in cultivation previous to that time were the Lawton and Dorchester. The former was a large, acid berry, liable to turn red and be unsaleable soon after being gathered for market; the latter was an early variety, sweeter, though not so large as the Lawton.

The Wilson Early was? an improvement on both of the others, being as early and sweet as the Dorchester, as large and productive as the Lawton, and retaining its bright, handsome color much longer. It was eagerly sought after by fruit growers and market men, and very naturally there was a large demand for plants, which sold at fabulous prices-as high as $\$ 1,500$ per 1,000 , and several dollars per plant in smaller quantities.

The first ten acres, planted in $\mathrm{I} 865$, yielded a heavy crop in 1867 , a principal part of which were sold wholesale at \$1 6 per bushel and a portion retailed from a fruit stand in Broadway, $\mathrm{N}$. Y., at one dollar per quart. 
The Wilson Early not only took the lead of all other blackberries at the start, but held that high position against all competitors as long as health and vigor lasted-until disabled by the infirmities of age.

Those who planted the most largely of it realized most money. of fruit.

One fruit grower planted seventy-five acres, and received $\$ 20,000$ in one year from the sale

Blackberries will run out, same as other fruits, and must be renewed from seed, either acci dentally, without regard to parentage, or systematically with a purpose to improve or perpetuate the good qualities of the best varieties. There was an opening for another blackberry, and the remark was sometimes made, that if a New Blackberry could be obtained possessing as good qualities as the Old Wilson had when young, and somewhat hardier, it would be all that could be desired in a blackberry. So far as I have learned, all the blackberries that have been sent out for general cultivation have been merely chance seedlings, accidentally found growing in neglected places, without any pedigree or record whatever to show their parentage.

Desiring to perpetuate the good qualities, large size and earliness of Wilson Early, selected berries of which measured three inches around, in 1875, reasoning from analogy and following the practice of the most careful breeders, who select the best animals, having the greatest number of good points, to breed from, I selected the Wilson Early as the standard of excellence in blackberries, having the greatest number of good points to be transmitted to its offspring, and planted seed of the largest berries from the thriftiest and best plants in preference to procuring accidental plants, which had no pedigree or back record to recomniend them.

Out of hundreds of seedlings thus grown from the Wilson Early, we selected, as the most desirable to propagate, the one called Wilson, Jr., which appeared to combine all the good qualities of the parent with some important additions. The fruit is large and early, is luscious and sweet as soon as black, holds its bright color, and bears carriage well.

The plants are hardy and productive; canes round, long, slender, enturely free from rust; bend over and strike root at the tips; sends up but few suckers; spines small and recurved; foliage large and thumb or mitten-shaped and generally has about the same appearance as its parent (the IVilson Early), and is substantially a reproduction of the excellent qualities of that good old variety, in a new berry, ripening earlier, more productive, and more than one-quarter of a century younger than the Old WVilson, from which it grew.

-For several years the superiority of Wilson, Jr., over its parent, the Wilson Early, growing by the side of each other, and other varieties near by, was manifest; and in a 30 acre field of blackberries, where all had an equal chance, seven rows of Wilson, Jr., yielded 24 quarts of berries per row at the first picking, being more than all others together in the field. At the second time the Wilson, Jr., yielded 50 quarts per row, being more than the Wilson Early, or any other variety in the field, and continued to pick as well during the season. A new Seedling Blackberry of such excellence, combining and perpetuating the good qualities of its parent (the IVilson Early) with some improvement-earliness, productiveness and evenness of ripening -is ample reward for the care and attention required for its selection and propagation.

With regard to hardiness it is about like its parent, the old Wilson Early, Dorchester and Lawton. We have frequently had inquiries from Carada and other places north, to know if the Wilson Junior would stand their climate, which we cannot answer without trial. In the extreme northwest, where all blackberries must be protected in winter, the Wilson Early has been preferred on account of its large berries and habit of growth, which renders it more easily covered than other varieties.

In July, $188_{3}$, the following notice appeared in the West Jersey Press :

The blackberry season has now commenced, with a fair prospect of a bountiful yield. It has long been considered one of our most paying crops, being of easy culture, and very productive, improved varieties yielding more than Ioo bushels per acre.

They are rapidly gathered by a class of people not worth much for other purposes, and sell readily in market for three times as much per bushel as corn. Many varieties in cultivation a dozen years ago, being Wildlings or Chance Seedlings, without any known pedigree, have so degenerated as to be nearly out of date, while their place is being filled by new seedlings raised by crossing such varieties as possess the most desirable qualities of large size and ertrliness. One fruit grower, who has been experimenting with them for many years, has succeeded in producing raluable fruit equally as large, more productive and earlier than the parents from which it originated.

Wilson Jumior was so produced, and has the best pedigree of any blackberry now in cultivation, being raised from the seed of the best selected fruit of the old celebrated Wilson Early. It is the largest and best very early blackberry, being sweet as soon as black, and not apt to turn red in the boxes, carries well and looks well in market, and sells readily at the highest price.

They were picked for market on the 6th of July, before any other variety in the neighborhood; and on the ninth a few rows yielded 200 quarts of large, handsome fruit, that compared favorably with the best blackberries known, such as the Wilson Early, Snyder, Dorchester, Lawton, Eureka, Kittatinny, Texas Early, Dehring's Early, Early Harvest, Gold Dust, Rioter, Brunton, and others which were commencing to ripen some fruit. 
On the same day (9th July) a number of prominent fruit growers and salesmen visited the plantation of Wilson Junior, and expressed their admiration of the heavy load of fruit, bending the bushes in graceful curves until they rested on the ground, laden with large and luscious fruit. Selected berries measured three and one-quarter inches around crosswise, and three and three-quarters inches around lengthwise.

There is no more certainty of raising a superior stock of plants without knowing the good qualities of their ancestors, than there is in raising superior cattle or horses without pedigree, and every person who offers such for sale, if he can show that their ancestors were the BEST STOCK OF THEIR KIND for a quarter of a century past, while health and vigor lasted, he has a guarantee that the offspring, whether it be a colt, a calf, or a blackberry plant, is of no mean parentage. BLOOD WILL TELL, and even a Jersey calf of Commasse stock is worth more than another, equal in size, age and beauty, without so good a record.

The value of PEDIGREE has long been appreciated, and its principles closely followed by breeders of horses, cattle, cereals and vegetables, and by its efficient aid the speed of trotters has been increased from 2.40 to 2.10: the yield of Jersey butter cows from 300 pounds a year to 778 pounds, with a fair prospect of exceeding 1000 pounds; and by pursuing the same course of pedigree breeding wheat, by means of repeated selections alone, the length of the ears has been doubled; their contents, (average number of grains) nearly trebled, and the tillering power of the seed increased five fold.

The same is true of melons, cabbage, turnips, beets and other vegetables propagated with regard to pedigree. And by following the same fundamental principle, the Wilson Junior blackberry has been produced three and a quarter inches around crosswise; being larger, earlier and more productive than its parent, the Wilson Early, which never exceeded, in the knowledge of the writer, three inches around crosswise.

Price of plants, 35 cents each, $\$ 2.50$ per doz., \$15.00 per I00; \$1 2500 per Icoo.

\section{PRICES OF BLACKBERRIES.}

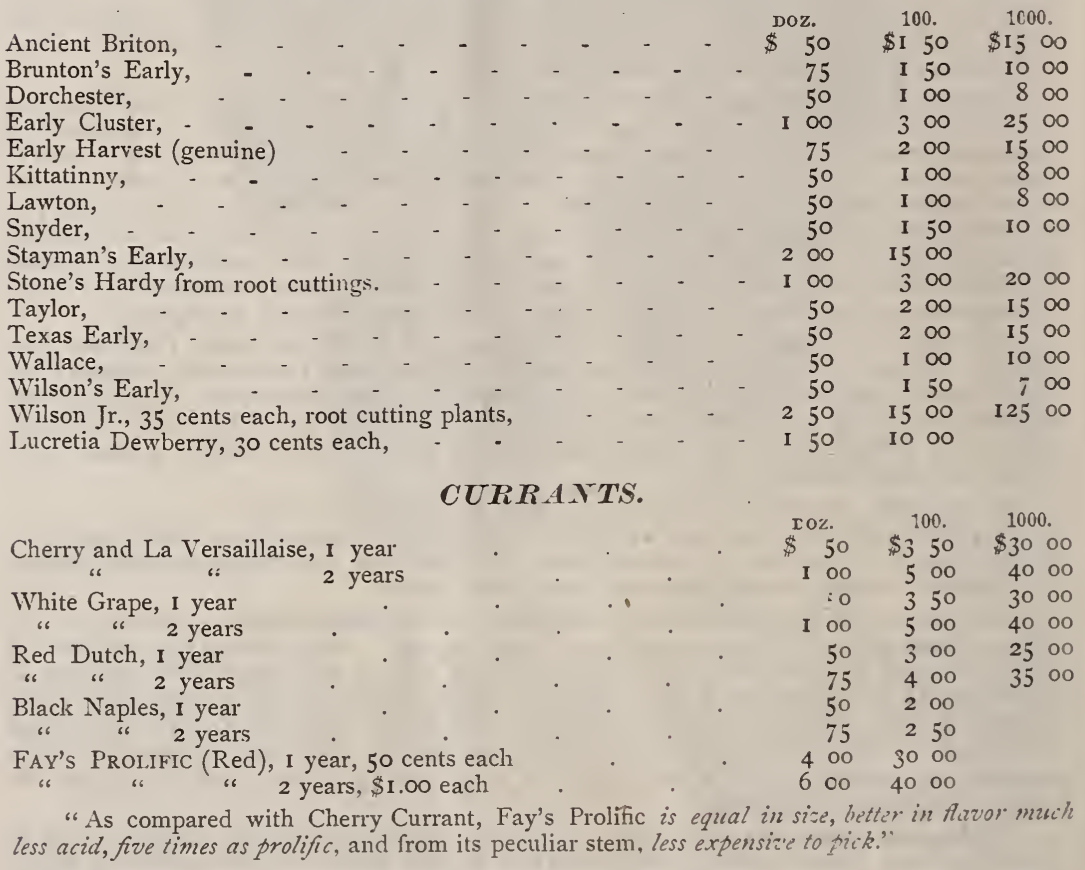




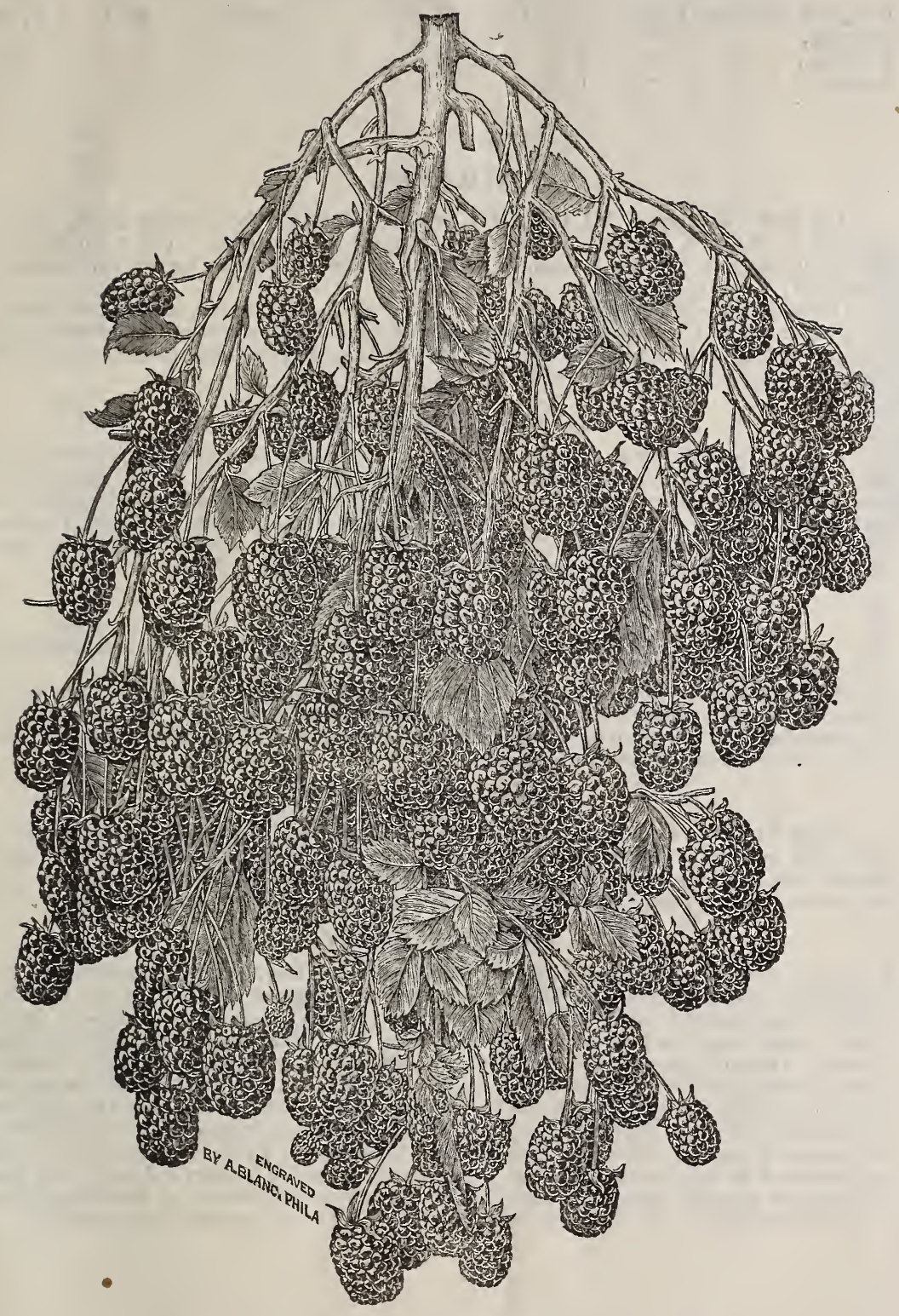

WILSON JUNIOR BLACKBERRY-REDUCED.

The above cut represents a cluster of WILSON JUNIOR BLACKBERRY, photographed from nature and reduced-see natural size, page 20 -one acre of which produced in $1884,1101 / 2$ bushels beside Wilson's Early, which yielded 53 bushels per acre, and in 1885, the same acre of WiLson JUNIOR produced I 63 bushels, and the same Wilson's Early adjoining, yielded 57 bushels per acre, under similar treatment and in equally good condition.

The Wilsow Junion also ripens the bulk of its crop in advance of the old Wilson. 


\section{GOOSEBERRIES.}

Houghton Seedlings, I year, Downing, Mountain, Smith's,

$\begin{array}{lcccc}\text { Doz. } & 100 & & \text { Doz. } & 100 \\ \$ 100 & \$ 300 & \text { 2 years, } & \text { I I } 50 & \$ 500 \\ \text { I } 00 & 600 & \text { " } & \text { I } 50 & 700\end{array}$

\section{GRAPES.}

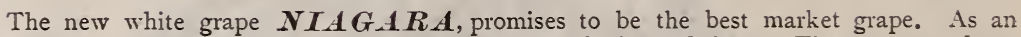
evidence of our faith we have planted three thousand vines of them. The company have decided to place this grape on the market and we will now book orders for two year plants (a) $\$ 2.00$ each; I year@\$1.00 each.

DESCRIPTION.--"Vine, very vigorous, hardy and productive; leaves, large, thick, downy ; wood, short jointed; bunch, very large, often double shouldered, very compact; berries, large, roundish oval, light amber, with a thin lilac bloom; flesh, meaty or solid, tender, juicy, sweet, slightly vinous, spicy-best for market."

\section{THE VERGENNES GRAPE}

"Is a chance seeding found growing in Vermont. It has now been in bearing several years, and has proved to be extremely productive; clusters, large; berries, large, holding firmly to the stems; color, light amber; flavor, rich and delicious, ripening as early as Hartford Prolific, and its keeping qualities are superior, lasting all winter almost as fresh as when picked. The vine is very hardy, strong, rapid grower. The leaf is large and downy. Its rich saccharine flesh, early ripening, late keeping and other good qualities, render it very desirable.

\section{DUCHESSE.}

"A New White Grape of excellent quality; vine, a strong, vigorous grower, hardy and very productive.

Buxch, medium to large, shouldered, compact; BERRIEs, medium, round, greenish white; SkIN, thin; FLESH, tender, without pulp, rich, refined and delicious; ripens with Concord. It has succeeded well, and given great satisfaction thus far, and will undoubtedly prove a valuable addition to our list of out-door hardy grapes."

\section{THE PRENTISS.}

DESCRIPTION.-_BUNCH, large and compact; BERRY, medium to large, yellowish green; SkIN, thin but firm; FLESH, tender, sweet, melting, juicy, with a very pleasant and musky aroma ; little pulp, few seeds; foliage, strong, thick and healthy ; vine, a moderate grower, very productive and hardy, standing uninjured with mercury fifteen to twenty degrees below zero.'

\section{MOORE'S EARLY.}

Combines the following desirable qualities: hardiness, size, beauty, quality, productiveness, earliness and is entirely exempt from mildew or disease. It onginated with J. B. Moore, Concord, IIass.; is one selected out of 2,500 seedlings, and is described as follows: Bunch, large; BERRY, round, large, (as large as Wilder) black, with heary blue bloom; QuALITY, better than Concord; very early, ripening ten days before the Hartford, and twenty days before Concord; VINE exceedingly hardy; has never been covered in winter, and has been exposed to a temperature of more than twenty degrees below zero without injury. "It first fruited in 1872 , and was then exhibited at the Exhibition of the Massachusetts Horticultural Society, since which time it has constantly been before the discriminating Fruit Committee of that renowned society. It has been awarded no less than thirteen First Premiums of the above society, and in the year I $\$ 77$ was a warded a special premium of sixty dollars. At the winter meeting of the Western New York Horticultural Society, ${ }_{1} \delta_{7} 8$, President Barry named it as the best new sort yet offered. 


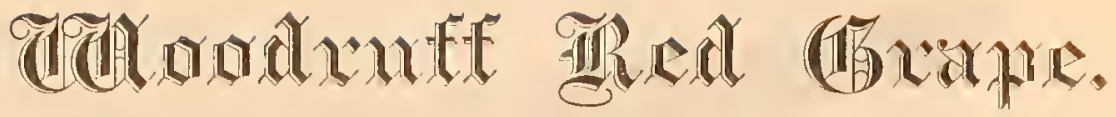

This very large and handsome red grape is a seedling of Concord, originated with $C$. H. Woodruff, Ann Arbor, Mich., in 1874. The vine is a very strong grower, free from disease and very hardy, never having been injured by the cold in the slightest, without any protection in winter, though the thermometer has reached 20 degrees below wero very often since its production. Bunch large, shouldered, berry very large and does not drop from stem. Exceedingly showy and has taken first premium over all competing varieties wherever shown. Its large size, both in bunch and berry, bright color and yeneral attractiveness make it especially valuable for market, it being sold in the Ann Arbor market for three times what Concords were selling at. A limited number of vines were sold for the first time without restriction, Spring 1885, and orders will be filled in the order received. Price for two-year vines, $\$ 1.50$ each, $\$ 15.00$ per dozen, $\$ 100$ per 100 . One-year vines, $\$ 1.00$ cach, $\$ 10,00$ per dozen, $\$ 75.00$ per 100 .

The following testimonal is from the Judge of Probate of Washtenaw County, Mayor of Amn Arbon City, and President of Am Amor School Board:

Tour new grape, "Woolln"tf Red," is the best I have ever eaten in Michigan. I cannot speak ton lighly of its qualities, Doth as regards, its becuty and flavor. I think it is destined to ranth umong the very foremost grapes raised in this latitude for the market and tathle.

Very respectfully yours, $\quad$ II. I). IIA RiRIMAN.

The following is from an Ann Arbor Fruit Dealer:

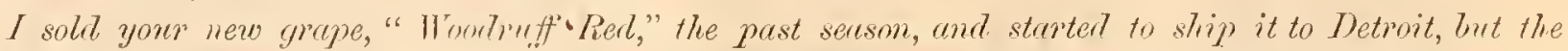
demand was so strong for it in Am A rbor thut I had none to send. It ontsells anything in the grape tive I have ever handled. It will bring three times whet the Concord will every time.

Yours truty,

WOHN H. GOULD.

The following is from the largest finit-grower of Washtencw County:

I am glarl to matie specird note of your new grape, the "Woorlruff Red," und checrfully recommend it to these who want a first cluss grape. It is remarkably healthy, rot nor mildem never having been formen upon it. It is a grape of good amulity, bunch, and. berry very larye, perfectly hurdy in enery respect and stunds the severest winters umprotected. It has been exhitited at several fairs and reciened first meminm in every instrance. The skin is very firm, and it has all the characteristics of a good lieeper. I hume eaten thern from the stems in the last weel of December, when they hat received no more care than being hept on a shelf in the cellar. In my experience I have not found its ergul, for canning jumposes, its fluvor being retained to a remarlable degree. Taking ath in all, it is one of the cumblitates for pullic furmor which cannot fuil to succeed upon its mun merits.

$$
\text { Lours respectfully, W. W. NICHOLS. }
$$




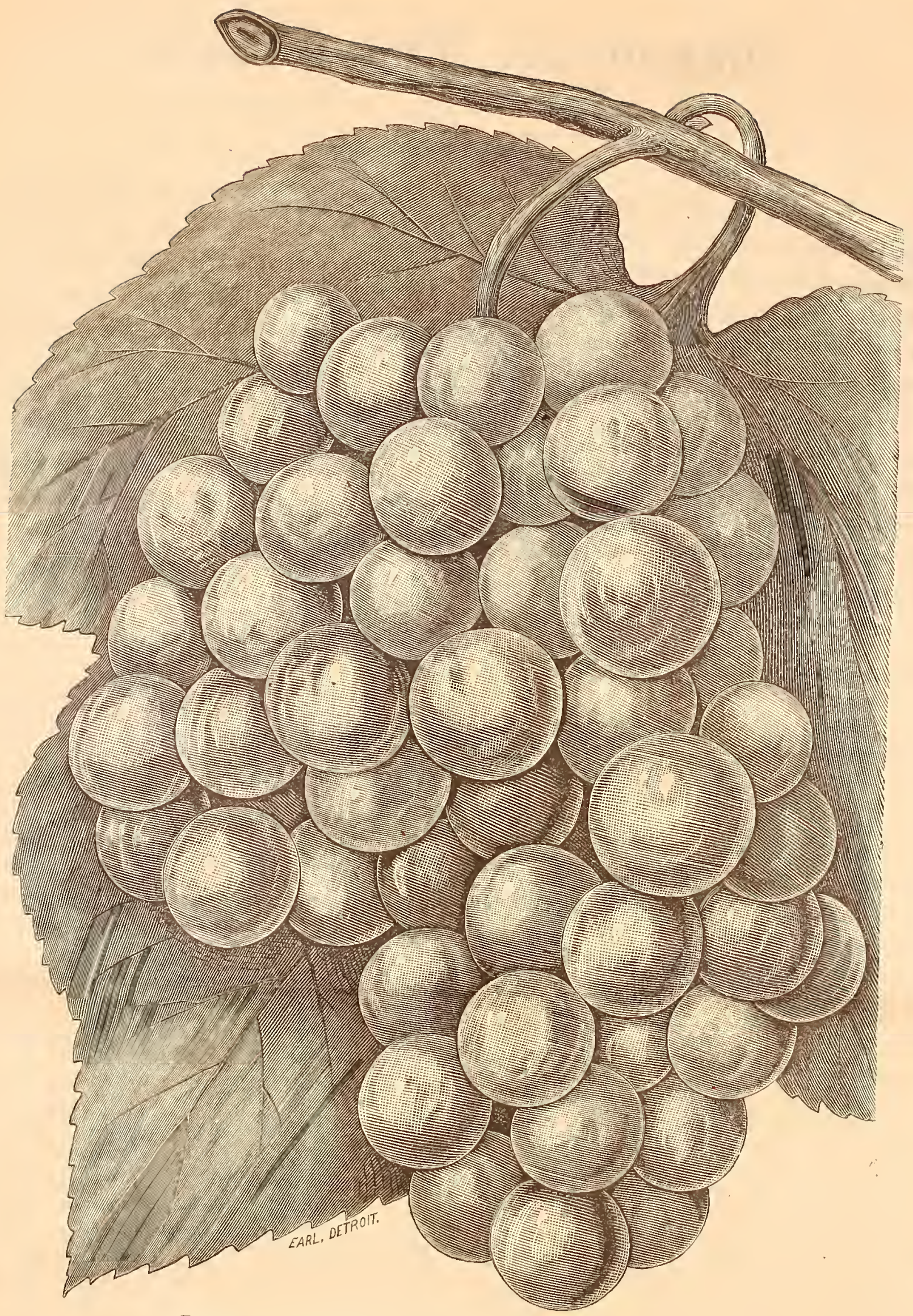

đoodpupf ped Grape.

(FROM NATURE. 


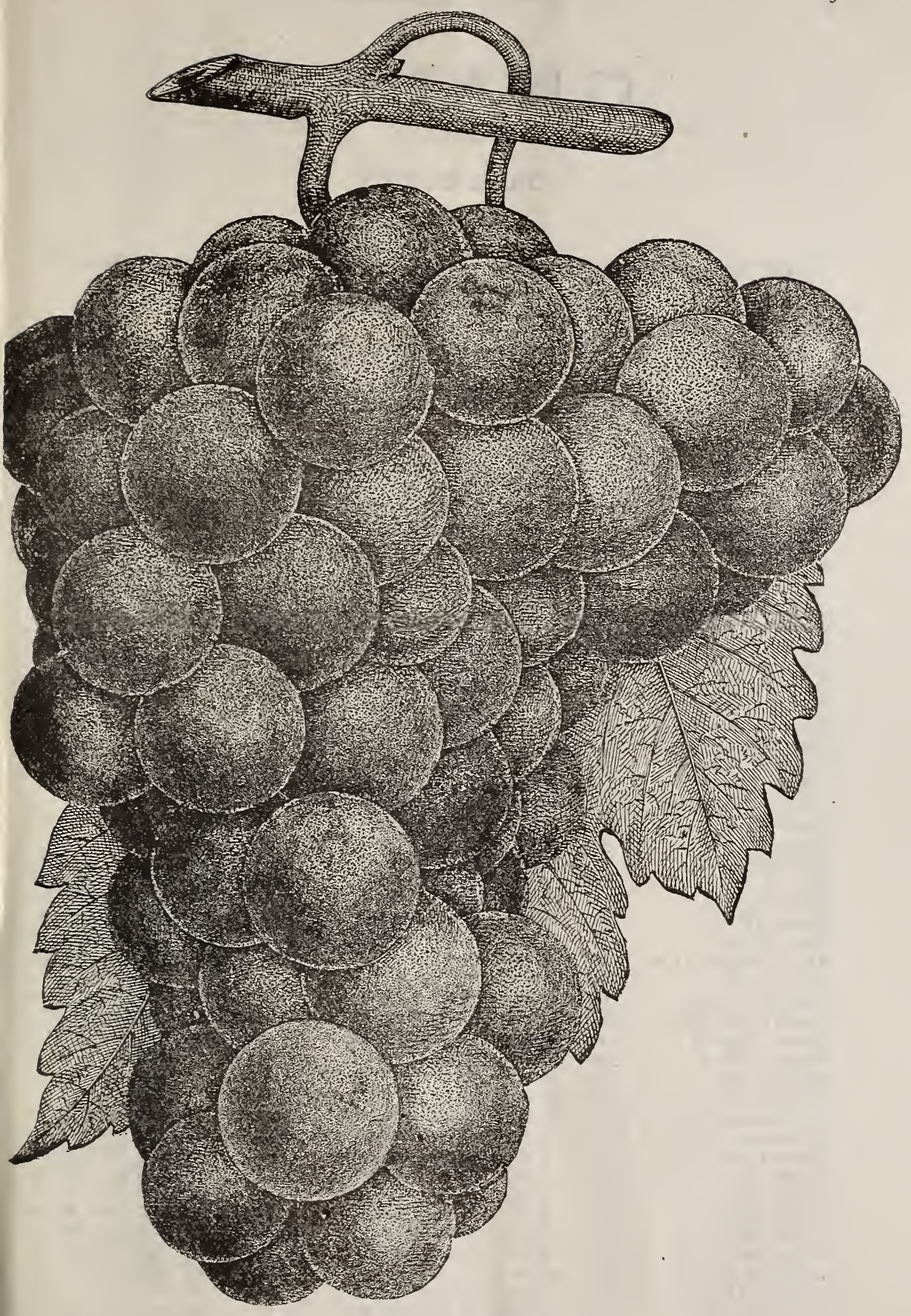

POCKLINGTON.

"The largest, most showy and most promising among the new, white, native grapes for market and general use. Vine perfectly hardy and free from mildew. 


\section{Gイ^「たS.}

FARDY.

The capitals denote the season of ripening, the small letters the color of the fruit.

In cash orders of $\$ 10.00$ or more we will furnish single vines at rate per 100 .

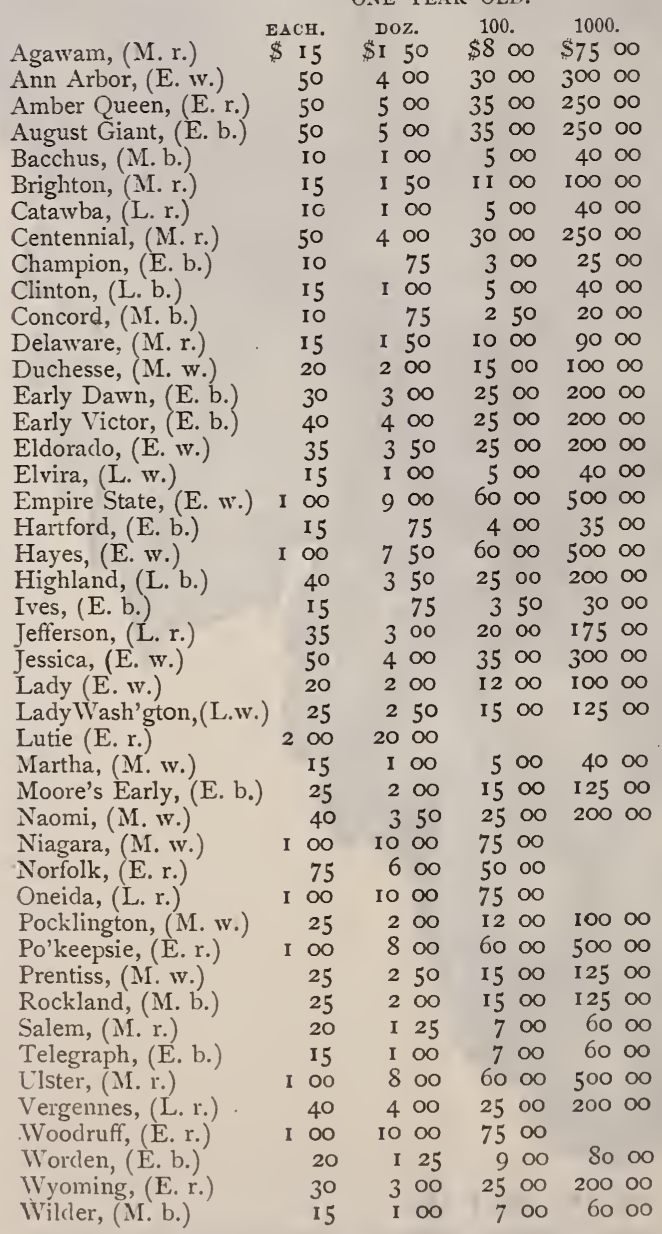

TWO YEARS OLD.

EACH. DOZ. 100.1000

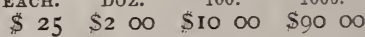

$\begin{array}{lllll}75 & 7 & 50 & 50 & 00\end{array}$

$75 \quad 750 \quad 5000$

I 5 I 50 10 00 7500

$25250 \quad 2000 \quad 17500$

I 5 I $50 \quad 750 \quad 6000$

$75 \quad 750 \quad 5000 \quad 40000$

I5 I $00 \quad 400 \quad 3000$

20 I 50 . 10 007500

25 I $00 \quad 600 \quad 5000$

$\begin{array}{lllllll}25 & 200 & \text { I } 5 & 00 & \text { I } 2500\end{array}$

$\begin{array}{llllll}30 & 300 & 14 & 00 & 12500\end{array}$

$50 \quad 500 \quad 4000 \quad 30000$

50 $450 \quad 3500 \quad 30000$

25 I $50 \quad 600 \quad 5000$

$20 \quad$ I $00 \quad 500 \quad 4000$

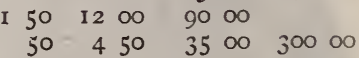

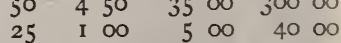

$\begin{array}{llllll}50 & 400 & 3500 & 300 & 00\end{array}$

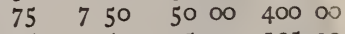

$\begin{array}{lllllll}25 & 2 & 50 & 15 & 00 & 125 & 00\end{array}$

$40 \quad 400 \quad 2500 \quad 20000$

$25 \quad 200 \quad 750 \quad 6500$

$\begin{array}{lllllll}35 & 3 & 00 & 25 & 00 & & \\ 50 & 5 & 00 & 40 & 00 & 300 & 00\end{array}$

$200 \quad 2000 \quad 17500$

Norfolk

Oneida, (L r $)$

Pocklington, (M. w.

Po'keepsie, (E. r.) I $\infty$

Prentiss, (M. w.)

Rockland, (M. b.)

Salem, (M. r.)

Telegraph, (E. b.)

Vergennes, (L. r.)

Woodruff, (E. r.)

Wyoming, (E. r.)

Wilder, (M. b.) 


\section{ASPARAGUS.}

Imperial or Colossal, 2 years,

Seed (Colossal), per lb., 30 cents,

\begin{tabular}{|c|c|}
\hline $\begin{array}{l}100 . \\
\$ \text { I }\end{array}$ & $\$ 400$ \\
\hline I oo & 300 \\
\hline
\end{tabular}

\section{RHUBARB.}

Victoria and Linnæus,

$$
\text { Doz. }
$$

100.

Small Packages sent by Mail at Retail Prices.

\section{CUTTINGS.}

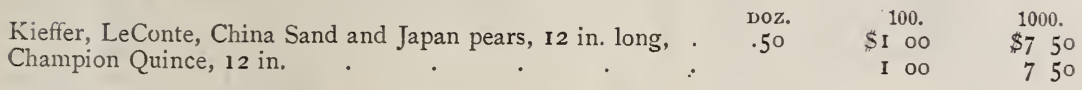

\section{SAMPLE SPECIMENS OF FRUIT.}

By mail, 25 cents each. By express, $\$ 1.50$ per dozen ; \$I.00 per half dozen.

Le Conte pear, during September; Kieffer, China and Japan pears, and Champion Quince, cluring October, November and December.

If any Stock we quote is offered by responsible parties at less rates for the same grade, we will furnish at the same.

\section{Ornamental Deparminent.}

\section{GRASSES. \\ GRASES.}

Arunda Donax Variegata,

Striped,

Erianthus Ravennæ, Io to I2 feet,

Pampas Grass, 5 to 6 feet,

Eulalia Japonica, variegated,

Eulalia Japonica, Zebrina,

Arborvitæ, American,

$\begin{array}{ll}\text { "witæ, American, } \\ \text { " } & \text { Siberian, } \\ \text { " Compact, } \\ \text { " Globe, } \\ \text { " Hoveii, } \\ \text { Ericoides, }\end{array}$

Arborvitæ, Pyramidal

$\begin{array}{ll}\text { " } & \text { Aurea Elegantissima } \\ \text { " " } & \text { " } \text { " Gaxwell } \\ \text { " } & \text { Tartaricum } \\ \text { " } & \text { Aroniana } \\ \text { " Borealis }\end{array}$


Retinospora Plumosa

EACH.

" Filefera

" Glauca

Box, Dwarf

$$
\text { "Tree }
$$

Eunonymous, Japonica

English Yew

Irish Yew, I foot

$$
\text { "Upright }
$$

Fir Balsam

“ Silver

" Nordmann

Juniper, Irish

$$
\begin{array}{ll}
\text { " } & \text { Swedish } \\
\text { “ } & \text { Prostrate } \\
\text { " } & \text { Japonica alba }
\end{array}
$$

Potocarpus Japonica

Pine, Scotch

$$
\text { " White }
$$

"Austrian

Spruce, Norway

" Hemlock

Aurea

HEDGING.

American Aborvitæ, 2 to 3 feet

$\begin{array}{cll}\text { "“ } & \text { " } & 3 \text { to } 4 \text { feet } \\ \text { Hemlock, } & & 4 \text { feet } \\ \text { " } & & 2 \text { to } 3 \text { feet } \\ \text { " } & & 3 \text { to } 4 \text { feet } \\ & & 4 \text { to } 6 \text { feet }\end{array}$

$\$ 1500$ 1800 2000 2000 2500 3500

\section{DEGIDUOUS SHADE TRPEES.}

Packing, 50 cents to $\$ 1.00$ per bale.

English Walnut,

Chestnut (Am.) " Spanish,

Elms, Io to 14 feet, Japan, 2 to 3 feet " 8 to 1o feet, " 6 to 8 feet

Horse Chestnut

Maple, Silver,

$$
\text { Scarlet }
$$

\footnotetext{
"Norway, I 2 to 15 feet

" " Io to 12 feet

" " 8 to Io feet

" Sugar, I 2 to $I_{5}$ feet,

" " $\quad$ Io to $I 2$ feet, " " 8 to Io feet,

$$
\text { " Ash Leaf, }
$$

Sycamore,

Scarlet,

Cypress,

Larch (European),

Linden (Am.),
}

TE Ten per cent, off and no charge for packing when cash is received with the order, except mail packages, on which we psepay postage. 
Linden (European),

Poplar, Aspen,

" Carolina, I 5 to 18 feet,

" 6 12 to I5 6

“ Tulip,

$$
9 \text { to I2 " }
$$

Willow, Weepıng,

" Laurel Leaf,

" Kilmarnock,

“ Rosemary,

" Golden,

“ Diamond, 3 to 5 feet,

Weeping Cherry, 2 yr., 4 to 6 feet

\begin{tabular}{lrl}
\multicolumn{2}{c}{ EACH. } & DOZ. \\
50 to & I 00 & 500 \\
50 to & 75 & 500 \\
50 to & 75 & 500 \\
40 to & 50 & 400 \\
25 to & 30 & 250 \\
60 to & 75 & 500 \\
50 to & 75 & 400 \\
25 to & 50 & 350 \\
50 to & I 00 & 700 \\
50 to & 100 & 500 \\
25 to & 50 & 100 \\
& 25 & 200 \\
& 30 & 300 \\
& I 00 & \\
& 100 & \\
& 100 & \\
50 to & 100 & 500 \\
25 to & 50 & 500 \\
25 to & 50 & 300 \\
25 to & 50 & 300 \\
15 to & 25 & 200 \\
50 to & 1 00 & \\
50 to & 1 00 & \\
50 to & 100 & \\
25 to & 50 & \\
&
\end{tabular}

100.

4000

3500

3000

2500

4000

2500

2500

Cut Leaf Weeping Birch,

Wier's Cut Leaf Maple,

Purple Beach,

Pawpaw, (northern banana or custard apple),

Judas (Japan)

" (Am.), 4 to 6 feet,

" " 2 to 4 feet,

Kentucky Coffee Tree,

Cork Oak,

Sweet Gum (Linn),

Catalpa, 6 to 8 feet,

\section{MAGNOLIA.}

Glauca, (the Jersey 'swamp Magnolia),-Very fragrant, 3-5 feet,

Conspicua.-Chinese.-This is the finest Magnolia in this latitude. In early spring it is covered with hundreds of white flowers as large as tulips. To these succeed a dark green foliage that lasts until late in the autumn.

I 00 to 200

Tripetela-Umbrella. - A small sized tree, with immense leaves and large white flowers, 4 to 6 inches in diameter,

Soulangeana-Very hardy, with large, beautiful white flowers, tinged with purple around the base; profuse bloomer; one of the best,

Acuminata-A noble tree with large leaves, flowers blush,

$\$ 50$ to $\$ 100$

\section{Rules for ascertaining the Number of Plants Required for One Acre of land, which contains 43,560 Square Feet.}

Multiply the distance in feet between the rows by the distance the plants are apart in the row, and their product will be the number of square feet for each plant or hill, which, divided into the number of feet in an acre, will show how many plants or hills the acre will contain, thus :

Blackberries,

Raspberries,

Strawberries,

Strawberries,

Dwarf Pears,

Peaches,

Standard Pears and Chesies, •

Apples, . . . 30

And so on for any distance that may be desired to plant.

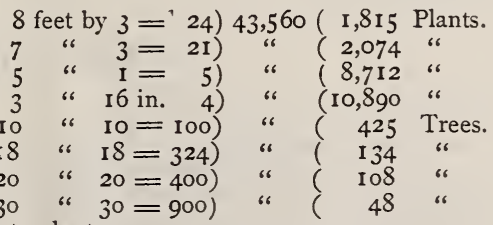




\section{VINES AND PLANTS BY MAIL.}

We invite special attention to the great accommodation now offered by the Post-office Department of sending by mail, vines, plants, seedling trees and grafts in packages of four pounds or less, (peach trees sent by mail in dormant bud only); so that all who are within reach of the best nurseries, and desiring to get supplied with stock, make selections from catalogue of the kinds wanted. Send P. O. Money Order on Moorestown, (not Morristown), N. J., or check or draft on Philadelphia or New York; or if bank notes are sent, the letter should be registered-and the plants will be returned by mail.

Safely packed in moss and oil paper.

Strawberry plants at the dozen rate will be mailed free. At the rates per 100, 20 cents additional must be remitted to pay postage.

Raspberries, blackberries, gooseberries, currants and grapevines will be sent by mail postpaid, if 2 cents each, 20 cents per dozen, 40 cents per 50 , or 75 cents per 100 be added to the price.

By the above arrangements, wherever there is a post-office, parties ordering may be sure of getting a first-class article delivered to them as safely as their letters.

Thus every family throughout the whole country has the opportunity of securing, by a small outlay, a complete and valuable collection of Small Fruits, Trees and Plants.

\section{HARDY AND ORNAMENTAL FLOWERING SHRUBS.}

Althea or Rose of Sharon, six sorts

Berberry-purple leaved, yellow

Calcycanthus or sweet scented shrub

Deutzia Gracilis, pure white

" Crenata, white tinted with rose

Forsythia-Golden Bell, yellow flowers

Hydrangea Panaculata Grandiflora,

Jassamine, yellow flowers

Lilac Prinee Camille de Rohan, large heads

" Persian, purple

Weigelia Rosea, rose colored flowers variegated leaved

White Fringe, pure white flowers resembling fringe

Viburnum Snowball

I'ucca Filamentosa, creany white flowers

Red Snowberry,

Tamarix Indica,

Purple Mist,

American Judas,

Japan Judas,

Pyrus Japonica,

Eunonimus Japonica,

Spireas-assorted,

Echeverias,

\begin{tabular}{|c|c|c|}
\hline EA & CH. & DOZ. \\
\hline & 25 & $\$ 250$ \\
\hline & 25 & 250 \\
\hline & 25 & $=50$ \\
\hline & 25 & 250 \\
\hline & 25 & 250 \\
\hline & 25 & 250 \\
\hline & $5^{\circ}$ & 500 \\
\hline & 25 & 250 \\
\hline & 25 & 250 \\
\hline & 25 & 250 \\
\hline & 25 & 250 \\
\hline & 25 & 250 \\
\hline & 25 & 250 \\
\hline & 25 & 250 \\
\hline & 25 & 250 \\
\hline & 25 & 250 \\
\hline & 25 & 250 \\
\hline & 25 & 250 \\
\hline & 25 & 25 \\
\hline 25 to & 50 & 250 \\
\hline 25 to & 50 & 250 \\
\hline & 25 & 25 \\
\hline & 25 & 25 \\
\hline & 25 & 2 \\
\hline
\end{tabular}

\section{HARDY CLIMBING TINES.}

Akebia Quinata, chocolate flowers,

Ampelopsis Quinquefolia,

Veitchii, suitable for clinging to walls,

Bignonia Grandiflora, Trumpet Creeper,

Clamatis Flamula, pure white star shaped flowers,

Climbing Roses, four best varieties,

Honeysuckles, four varieties,

English Ivy, beautiful green foliage,

Wisteria Chinese, pale blue flowers,

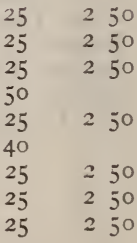




\section{FOOD CARP.-Purti-Scale.}

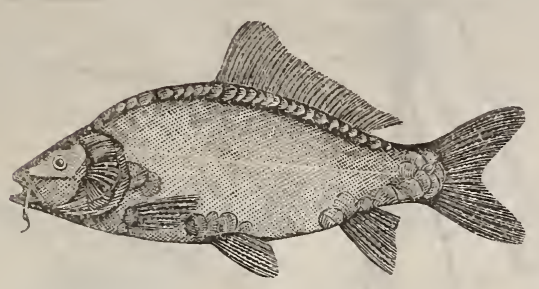

The only food fish that can be profitably cultivated in inland waters.

Having procured the improved Carp through Prof. S. F. Baird, U. S. Fish Commissioner, from the Government Ponds at Washington, D. C., and had our ponds constructed under the supervision and approved plans of M. P. Pierce, we will furnish young Carp, pure and genuine, for stocking pond.-Hybrids are worthless.

\section{I'ILLIAM PARRI,}

President American Carp Cultural Association.

N. B.-Correspondence relating to the Association should be addressed to Wilton P. Pierce Secretary, 44 North Fourth Street, Philadelphia, Pa.

We have a fine supply of this valuable food fish, with which every farm should be stocked.

Our Fish are pure, genuine and unmixed.

\section{PRICE OF FOOD CARP.}

Hatch of present year, for sale in the Fall, One year old, for sale Spring or Fall, Two years old (Breeders), Special rates by the 100 or 1000 .

Shipping cans, 50 cents to $\$ 3.00$ each.

\section{WATER EILIES.}

For stocking Carp Ponds, not only supply food for the fish, but beautify and ornament the ponds.

Price-Nymphaea Oderata (Common Pond Lily);

Nelumbium Luteum (American Lotus),

$\$ 25$

$\$ 200$

Nelumbium Speciosum (Egyptian Lotus),

\section{AYRSHIRE CATTLE FOR SALE.}

Several young Bulls, Cows and Heifers; all registered and best Milking Strains. 


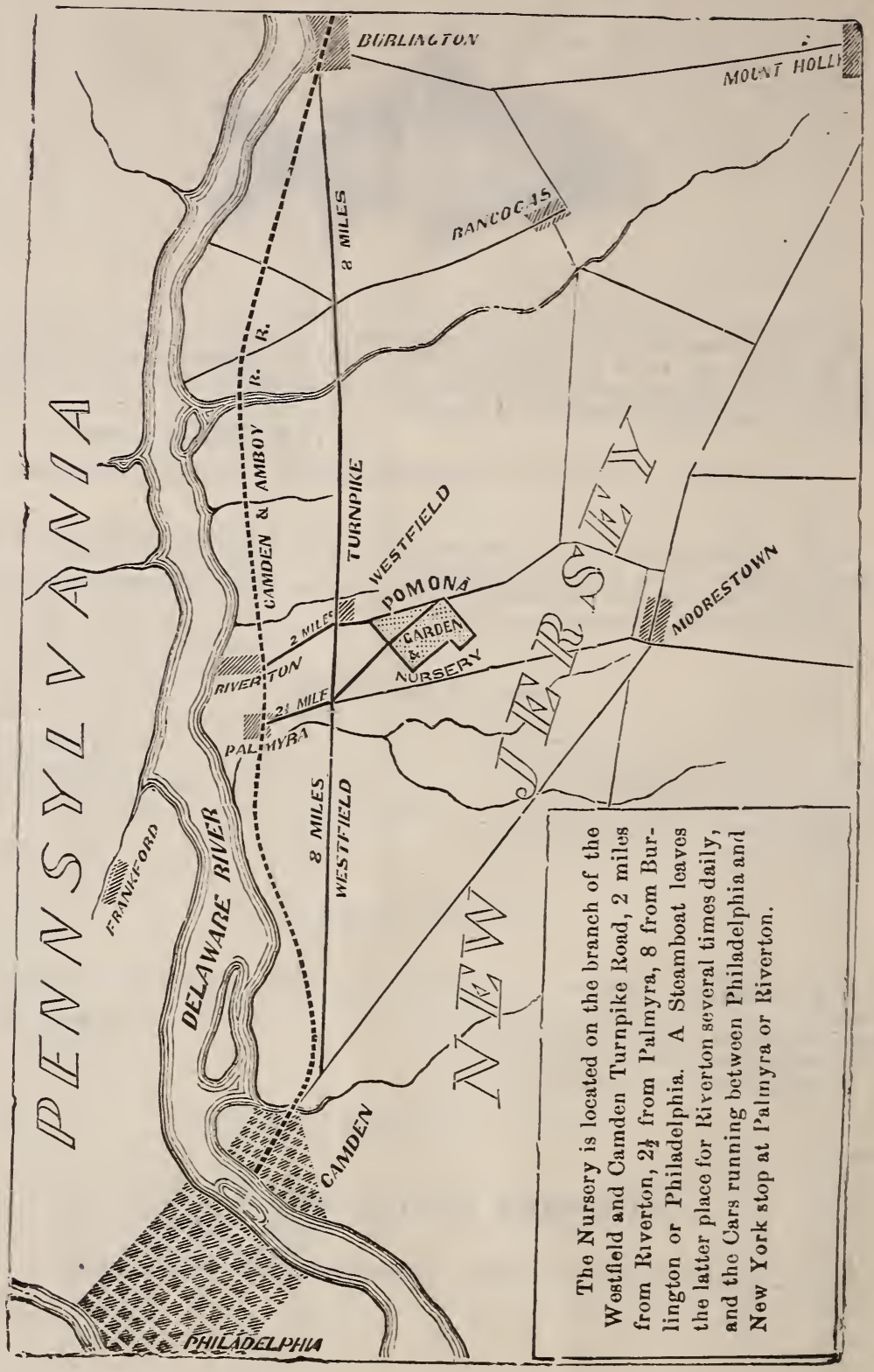




\section{$\alpha$ What Pears to Plant in New so Jersey for Profit.}

The following-paper was read before the New Jersey State Horticultural Society at its Annual Meeting held in Trenton, December 29th and 30th, 1885, by William Parry.

New Jeriey soil varies greatly in its character from light blowing sand to heavy loam and clay. Pear culture is subject to so many contigencies as location, climate and texture of soil, insect enemies, blight and fungus; and the character of our land changes so frequently that a pear that is well adapted to one location may not be suited in another, and it is found that the experience of fruit growers differ on this subject, each one recommending the variety that has done well with him, while perhaps it would not do so well in another location not far distant.

It is a good plan for a beginner to consult with his neighbors or nearest nurseryman as to the kinds that as most called for, generally planted and do best in that neighborhood, then by planting a few of each kind that do well for others in that section he will be very likely to get some that will be profit ble. Then from his own experience(which is the best of knowledge) he can enlarge his orchard with kinds best suited to his location, soil and climate. Fifty years ago this same question was pertinent among fruit growers. Previous to that time it had been my lot to assist my father in attending to his fruit orchards of ap:les, pears, peaches and plums in pruning, cultivating and gathering the fruit f'or market (on the same premises which I have ever since occupied). At that time the principal pears we cultivated were the old Butter pear or White Doyenne, Seckel, IValnut, St. Germain, Bensels Winter and Caue May. Desiring to enlarge our pear orchard and not knowing what peurs to plant for profit, I adopted the plan above recommended to others, viz: to try several of those most likely to succeed and hold on to those which best answered the purpose for which they were wanted.

In 1840 I imported from Audre Le Roy, France 31\%, varieties of the most desirable according to my limited knowledge, and planted them all in one orchard. They yielded as high as $\mathbf{2 8 4}$ varieties at one time, for which the highest premium was awarded at the Agricultural Exhibition in Burlington Co., N. J. The experiment was very interesting and the information obtained valuable,proving clearly to my mind that fo: profit it is better to have but few kinds of the most salable varieties rather than to have the orchard filled with many kinds and but few of each.

From the experience above referred to and some additions more recently made I make the following selection which will be likely to do well for those who have a similar soil, location and climate to ours, in the Northern part of Burlington County, New Jersey, about eight miles East of Philadelphia. List for Amateurs:

Lawson, Summer Doyenne, Boussock, Vienna, Tyson, Leconte, Sheldon, Bosc, Elizabeth, Giffard, Nargaret, Chambers, Bartlett, Seckle, Bell Lacrative, Howell, Clapps Favorite, White Doyenne, Frederick Clapp, D'Esperen, Angoulime, Brockworth Park, Pitmaston Duchesse, Kieffer, Emile d' Hyst, Anjou, Dana's Hovey, Josephene of Malines, Lawrence, Quinn and Winter Nellis-31, or about one tenth, of the number tested in our experiment grounds, is all that I can recommend as having special merit.

If I were to select three as being the most delicious pears to eat they would be Bell Lucrutive, Seckle and Lawrence: but not to sell in market for profit, they are not attractive enough to bring a high price, and must sell low. Size Ind bechity are the two essential points to make fruit sell well. No matter how good fruit may be it must please the eye or purchasers will not buy. For three of the most desirable pears to plant in New Jersey for profit, having regard to all the circumstances that enter into the combination necessary to profit, viz: location, soil and climate, vigor, productiveness, early and regular bear. ing, from my present knowledge and limited experience, I would name 1st, Lawson the most beautiful pear of medium size ripening in July and sells higher in market than any otiler pear ripening at the same time. $2 \mathrm{nd}, \boldsymbol{B}(\boldsymbol{u})^{\prime} t \mathrm{l}^{t} \boldsymbol{t} t$ the most popular pear ever grown here, beautiful to look at and tempting in appearance; color yellow, rich as an orange, and sells higher than any other pear at its time of ripening, hence we hear the remark that no other pear is wanted when Bartlett's are ripening, but their season is short and when past there is a demand for a later variety fortunately we have for the 3rd the Kieffer which is larger and (if possible) handsomer than the Bartlett, having a beautiful red blush on a rich yellow ground and com. mands a higher price than any other pear 
in the market at its time of ripening. We have sold several hundrerts of bushels of Kieffer's this year which brought fiom $\$ 1.75$ to $\$ 2.00$ and upwrards per bushel, more readily than good Lawrence pears would bring one half as much.

I know a man who has commenced planting a pear orchard in Virginia for profit, and his selection of varieties is 20 cres of Briletts, ?O acres of Kieffer, 15 acres of Lauson, $21 / 2$ acres of Bell, $21 / 2$ reves of Orunge-60 acres. If the location, soil and climate suits them as well there as here in New Jersey I don't see how it could be improv. er. It is by comparison that we juage the inarket value of fruits.

At the World's Exhibition held in New Orleans about one year since, where the greatest collection of fruits from the widest extent of country ever brought together under one roof were shown, 5 premiums were awarded for Kieffer Peru's. One for best plate, largest and handsomest pears 1 st premium $\$ 10$, and a special premium for a display in glass (canned) of unusual excellence and becuty, a silver medal and an other for a fine display of Kieffer pears, 1st premium \$10. And another for the handsomest plate 12 specimens, 1st premium \$10, and one for best plate of Kieffer's, \$5. Those premium pears were all grown on trees free from the influence of quince sap.

"Poor, Poor Kiefier" so called, was only awarded at the World's great Exhibition where 20,000 plates of fruits were dislayed; double the number ever before hown at one time), 5 groud prizes, inluding a silver medal for a display in lass of unusual excellence and becuty, and inother first premium of $\$ 10$ for the best late, largest and handsomest pears, and two ther first premiums of $\$ 10$ each for Kieffer pear's and one of $\$ 5$ for best plate of Kieffer.

We have for several years past published n our annual catalogues and other cireulars, that quince stocks are not congenial to Kieffer, Le Conte other hybrids and oriental pears.

Quince sap is poison to Kieffer pear trees, and they should never be propagated from dwarfs grown on quince. The health and constitutionality of many Kieffer pear trees have been permanently injured by using buds or scions cut from dwarfs grown on quince, thus infusing into the yeins of the future trees the poisunous quince sap, which can no more be worked out again than native blood can be worked out of Jersey cattle after once being admitted, but the adulteration will descend to future cenerations.

I have never known a case of blight on a pure Kieffer Hybrid pear tree which was free from quince sap; but I have seen many trees called Kieffer turn black and rie of blight when the cause could be traced to the poisonous influence of quince sap which descended from their ancestors.

We have planted 25 acres of pure Kief$f e r$ pear trees free fror quince sap and have no blight on them; we also planted 3000 dwarf Kieffer's grown on quince and 300 of them died of blight during the first year and as many more every year since intil there is biit a few scattering trees left which having thrown out roots from the Kieffer above the quince roots may prolong their life a little longer. No pear trees propagated from dwarfs grown on quince are as healthy as trees that have always been grown from standards.

The vital powers of the pear are avow edly checked in favor of the reproductive, when it is grown on quince and plants propagated from such trees will partake of the low vital powers engendered and be more liable to disease and blight. Buds taken from such trees carry with them the seeds of their own destruction, having the same properties in embrio as the tree from which they were taken, and like peach buds cut from trees affected with the yellows, the poison or disease is transmitted to the young stock, its vitality impaired and although it may appear healthy for a time it is rendered liable to blight and preniaturely dies. Persons about to plant the Kieffer. Leconte or other Hybrid pear trees should stipulate that their antecedents were free from any contamination with quince.

We have so often cautioned the public on this subject through our annual catalogues and circulars that if the readers thereof, regardless of our experience and advice, wi!l invest in Keiffer's, whose antecedents were grown on quince, and there is "wailing and profanity among the victims" as we predicted, "it is certainly no fault of ours.'

In answer to the question what pears to plant in New Jersey for profit, being governed by our experience and observation must say Lawson, Bartlett and Kieffer about cover the time from July till December without interfering or conflicting with each other; all are strong, healthy, vigorous growers, when free from quince sap, commence bearing early, yield abundantly of beautiful pears which command the highest price in market at their time of ripening.

The foregoing is a recital of our experience in Pear growing. For more that fifty yerrs past it has been successful here, and we know of no better guide, for similar soil, climate and location. It has been our practice to test all Pears that promise well and hold fast to those that are profituble.

We could not afford to grow many Pears without profit, merely for the luxury of eating them. WILLIAM PARRY,

Parry P. O., N. J. 


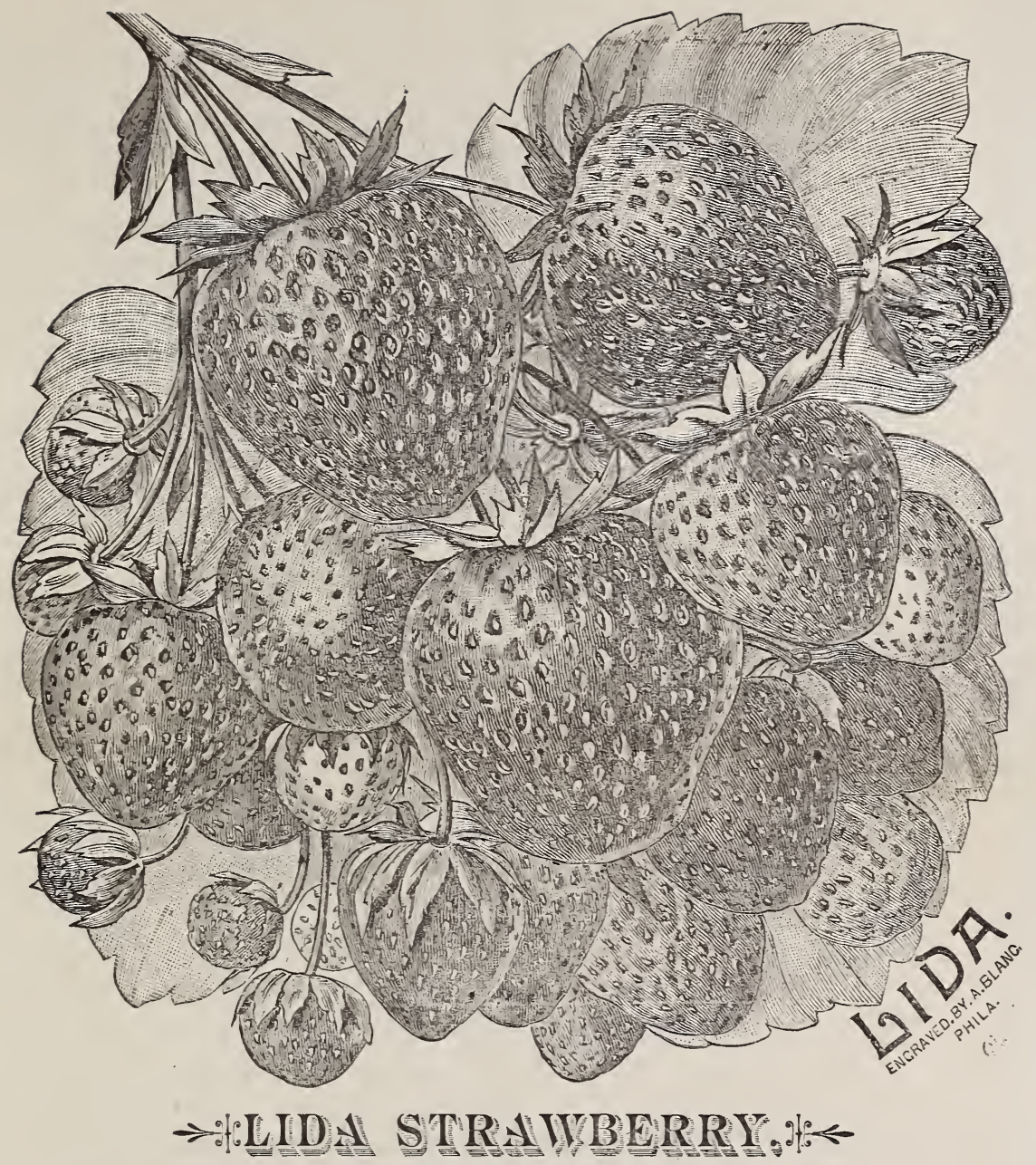

A promising seedling, raised from E. W. Durand's large strawberry, the KING CLUSTER, in I880. It is a pistilate variety, large size, very productive, bright red color, heart shape, regular, and uniform in appearance, ripens medium season, firm in flesh, a good shipper and excellent quality. Producing as many berries as Crescent and much larger in size. It is a strong, robust grower but will not make as many plants as the Crescent. A limited number of plants for sale Spring, I886.

$\$ 1.00$ each, \$10.00 per doz., \$75.00 per I00.

WITLIAM PARIR,

Parry, NeW Jersey. 
Samula C. DeCou, Moorestown, N. J., nurseryman and extensive strawberry grower, says of $t$ : "A handsome, bright red berry of very good quality, firm, nearly the size of the Parry. Being a pistilate it occurred to me that a field of the Lida, alternated with the Parry, to fertilize it, would be an excellent arrangement."

Jno. T. Lovetr, Little Silver, N. J., editor of Orchard and Garden, introducer of Manchester strawberry, Cuthbert raspberry and other valuable fruits; also first to recognize the sterling merits and call our attention to the Parry strawberry among a number of others in the seedling beds, says: "The Lida strawberry as I saw it at Pomona Nurseries in full bearing excelled, in combining the three points productiveness, size and market qualities, any other strawberry I have ever seen. The berries were not so large as the Parry but larger than Chas. Downing, very pretty, exceedingly uniform and fully equaled in firmness the Wilson. I think it has a great future. I wish you would give me your best price for a thousand of the Lida to be delivered next Spring."

Theo. F. Baker, Brilgetón, N. J., Pres. N. J. State HorticulturalSociety, market gardener and extensive strawberry grower, says: "In $r$ ferring to my notes taken on a visit at Pomona Nurseries, June, I 884, I find Lida : pistilate, foliage good, very prolific; berries large and uniform in size; color, bright red; flesh, firm; quality, good. Though first impressions are not always lasting, in this instance a better acquaintance has strengthened first impressions and from observations and experience with Lida on my own farm this season I can fully endorse the above impressions, and also add that the Lida is a truly wonderful plant, and is to the strawberry what the Siamese twins is to the human family-as with me ncarly cuery runner produces a double-crorened plant at each joint--two distinct crowns united at the base, and roots supporting each plant-a feature I have never seen with other varieties. It stood the extreme heat of the past Summer and made a strong growth, especi.lly noticeable among eight other varieties in the same patch."

The following remarks of P. M. Augur, the originator and introducer of the Jewell strawberry, in Practical Farmer, are especially applicable to the Lida: "Pistilate varieties are often among the best and most productive and are especially well adipted to high culture and single rows, alternating with a bisexual variety should well match the pistilate, especially in the time of blooming, in order to make a full success. The strong cone of the pistilate with the abundance of zollen from the other, often result in the most abundant and satisfactory fruitage and success."

WILLI M PARRY. 


\section{THE GARDENER'S MONTHLY AND HORTICULTURIST}

Edited by Thomas Meehan and pulplished by Charles H. Marot, 81 4 Chestnut street, Philadelphia, at \$2. Io per year. gives full instructions in the science and practice of every branch of (rardening. It will pay any one to subscribe for it. My friends and customers may send their sulscriptions through me if they prefer, and I will forward them to the publisher-

THE FARMERS' ENGINE.

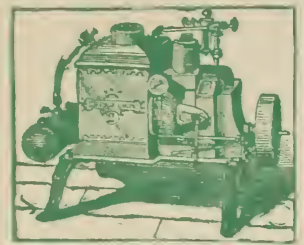

NO ENGINEER.

NO DANGER.

NO EXPLOSION.

NO FIRES.

NO SPARKS

NO ASHES

C'osts 20 Cts. per Day for Fuel. Once starte 1

it takes eare of itself. For Prices and Circular, address.

CIIA RLES PARIR. Parry, N.J.

\section{FOR \\ CRATES AND BASKETS}

A DDR EST,

C. PARRY, PARRY P. O., N. J.,

Who is now manufacturing and offers for sale the following very superior Berry Baskets and Crates:

\section{DELAWARE QUARTS AND PATENT CRATES.}

We have thoroughly tested, within the last forty years, all the approved berry crates and baskets now in use, in shipping annually hundreds of bushels of small fruits to market, and have selected the above as most desirable for carrying fruit in good condition.

They are light, strong, well ventilated and cheap; and in them fruit carries best, looks best and sells best in the market.

The baskets may be nested closely together, each crate holding one hundred or more, so that surplus baskets may be ordered without increasing the freight.

When ordering goods C. O D., please forward ten fer ient. of the amount of bill with order 


\section{0}

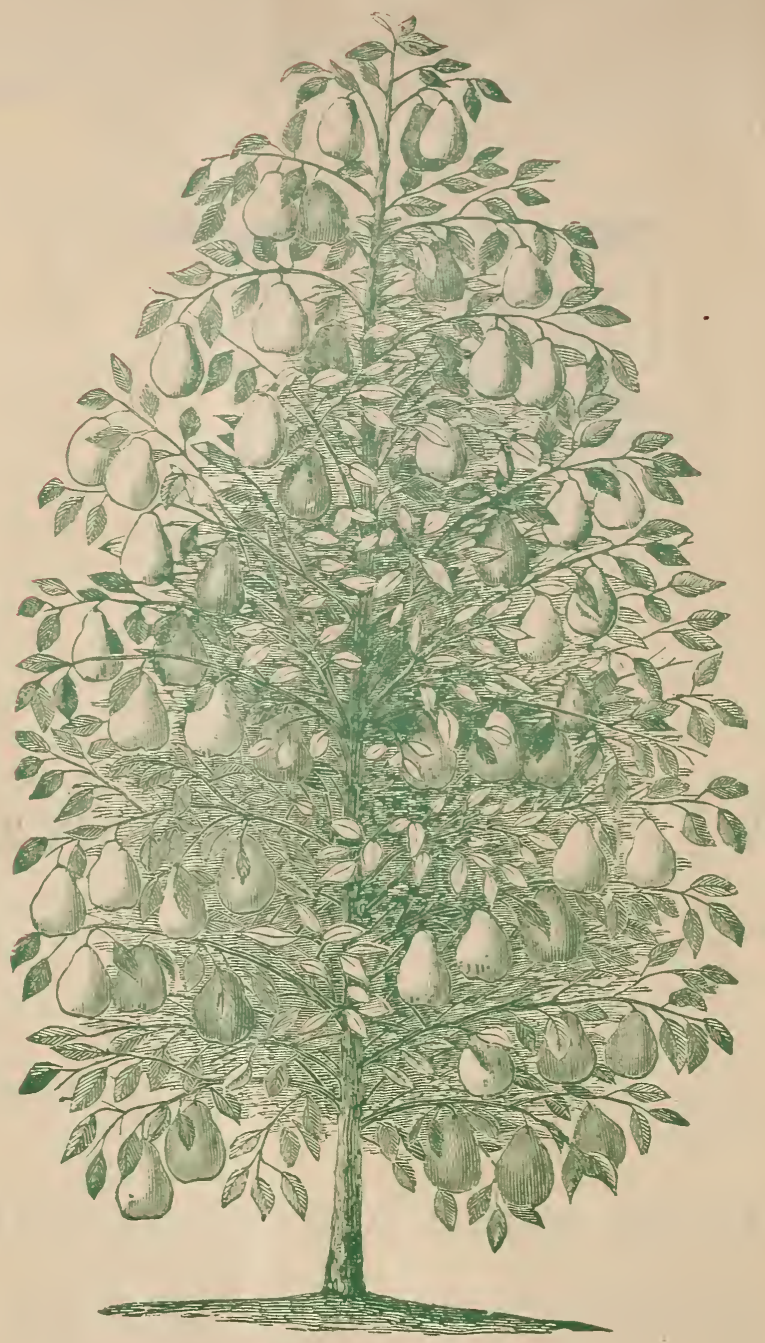

LAwsox, the largest and most beautiful Pear of good quality ripening in July.

The ORiginal TReE, ioo Years or more old, has never been affected with blight or other disease, still stands healthy and vigorous on the Lawson Estate, and was first disseminated by them in a commercial way on condition that it be propagated and sold under its true name of Lawson Pear. 